\section{Do Cultivars of Native Plants Support Insect Herbivores?}

\author{
Emily C. Baisden ${ }^{1,3}$, Douglas W. Tallamy ${ }^{1,4,7}$, Desiree L. Narango ${ }^{1,5}$, \\ and Eileen Boyle 2,6
}

ADDITIONAL INDEX WORDs. conservation, garden, biodiversity, anthocyanins

Summary. Native plants are becoming widely used in built landscapes to help mitigate the loss of biodiversity caused by urbanization. The primary advantage of native plant species over introduced ornamentals is their ability to support the development of the insects that fuel vertebrate food webs as well as specialist pollinators. The horticultural industry has introduced many cultivars of native plants to improve their aesthetic value and disease resistance, but there has been little work that measures the impact of these genetic changes on insect herbivores and pollinators. Here we measure how six desirable traits in native woody plant cultivars (leaf color, variegation, fall color, habit, disease resistance, and fruit size) compare with their wild types in terms of their ability to support insect herbivore development, abundance, and species richness. Using a common garden experiment, we quantified the abundance and diversity of insect herbivores using each species and its cultivars for growth and development over a 2 -year period, as well as cumulative feed damage over the entire season. We also conducted feeding tests with evergreen bagworm (Thyridopteryx ephemeraeformis) to measure the preference of hatchling caterpillars for cultivars vs. straight species. We found that cultivars that had leaves altered from green to red, blue, or purple deterred insect feeding in all three experiments, a preference for variegated cultivars in one of our three experiments, but no consistent pattern of use among the species and cultivars chosen for other traits. These results suggest that the usefulness of native cultivars in restoring insect-driven food webs depends on the cultivar trait that has been selected.

$\mathrm{T}$ The dominant landscaping practice of recent centuries has been to create landscapes designed with ornamental plants that have been introduced from other countries. This practice has been so pervasive that nonnative plant species now outnumber native species in most urban, suburban, and rural landscapes (DeCandido et al., 2004; Dolan et al., 2011; McKinney, 2006, 2008; Qian and Rickleffs, 2006; Standley, 2003). For example, an extensive study of landscape plantings

We thank Mt. Cuba Center for financial, logistical, physical, and philosophical support for this project; George Coombs for invaluable help in locating sources of appropriate cultivars; George Coombs, Amy Highland, and four very thorough reviewers for helpful comments on the manuscript; and Mt. Cuba staff for assistance while planting our common garden experiment.

${ }^{1}$ University of Delaware, Department of Entomology \& Wildlife Ecology, 250 Townsend Hall, Newark, DE 19716

${ }^{2}$ Mt. Cuba Center, 3120 Barley Mill Road, Hockessin, DE 19707

${ }^{3}$ Masters graduate.

${ }^{4}$ Professor.

${ }^{5}$ Doctoral graduate.

${ }^{6}$ Director of Education and Research.

${ }^{7}$ Corresponding author. E-mail: dtallamy@udel.edu.

https://doi.org/10.21273/HORTTECH03957-18 in Washington, DC, suburbs measured $55 \%$ nonnative plant biomass (Narango et al., 2017). This imbalance is perpetuated by nursery stock dominated by nonnative ornamentals. A study done at Mt. Cuba Center, a botanical garden dedicated to native plant horticulture and research in Hockessin, DE, found that large mid-Atlantic U.S. wholesale nurseries carried only $25 \%$ native species (Coombs and Gilchrist, 2017).

There is growing evidence that the preponderance of nonnative plants in built landscapes may impact the conservation of local biodiversity. Although nonnative plants can extend nectar resources late in the season (Salisbury et al., 2015), their exclusive use in pollinator gardens pose a threat to the dozens of native bee specialists that only reproduce on single native plant genera (Fowler, 2016). Moreover, because native plants support the growth and development of the insects that transfer the most energy from plants to vertebrate food webs far better than nonnative plants (Burghardt et al., 2010; Pearse et al., 2013; Tallamy, 2017; Tallamy and Shropshire, 2009), the lack of native species in urban ecosystems depresses populations of the wildlife that helps run those ecosystems (Burghardt et al., 2008; Narango et al., 2017). This is particularly true for the terrestrial birds in North America, 96\% of which rear their young on insects [derived from Peterson (1980)].

There is increasing interest in gardening for wildlife, and consequently a growing market for native landscape plants (American Society of Landscape Architects, 2017; Brzuszeki and Harkess, 2009). This, in turn, has led to questions regarding what is "native" and what is not, what are appropriate constraints from plant provenance, and, most often, are cultivars of native plants (often called "nativars") the ecological equivalents of the parent species from which they were selected? This last question is particularly important because the increased use of native plants is being driven more by their ecological function in the landscape than by their aesthetic roles. Moreover, the majority of native plants in the nursery trade are available as cultivars (Coombs and Gilchrist, 2017).

There are two primary ways cultivars may impact the insects that use plants for growth and reproduction: 1) A genetic change that creates a desired cultivar trait may alter the leaf chemistry of the plant to the point where insect herbivores no longer recognize the plant as a potential host or are repelled by an increase in distasteful feeding deterrents; 2) cultivars that change the color, shape, or

\begin{tabular}{lllc}
\hline $\begin{array}{l}\text { Units } \\
\text { To convert U.S. to SI, } \\
\text { multiply by }\end{array}$ & U.S. unit & SI unit & $\begin{array}{l}\text { To convert SI to U.S., } \\
\text { multiply by }\end{array}$ \\
\hline 0.4047 & $\mathrm{acre}(\mathrm{s})$ & $\mathrm{ha}$ & 2.4711 \\
0.3048 & $\mathrm{ft}$ & $\mathrm{m}$ & 3.2808 \\
0.0929 & $\mathrm{ft}^{2}$ & $\mathrm{~m}^{2}$ & 10.7639 \\
3.7854 & gal & $\mathrm{L}$ & 0.2642 \\
2.54 & inch(es) & $\mathrm{cm}$ & 0.3937 \\
25.4 & inch(es) & $\mathrm{mm}$ & 0.0394 \\
6.4516 & inch & $\mathrm{cm}^{2}$ & 0.1550
\end{tabular}


phenology of a flower may inadvertently reduce the amount or quality of the pollen and nectar available for pollinators, or, in the case of double, sterile flowers, may eliminate pollen and nectar altogether. In this study, we focus exclusively on the potential impacts of native cultivars on insect herbivores and leave flower modifications for a later study. Specifically, using a common garden experiment and laboratory feeding preference trials, we measured how six common cultivar traits of trees and shrubs that modify leaf color, disease resistance, fruit size, and plant habit impact the feeding preference, abundance, and diversity of insect herbivores.

\section{Methods}

\section{Common garden experiment}

In May 2014 we planted a $1500-\mathrm{ft}^{2}$ common garden experiment at $\mathrm{Mt}$. Cuba Center. The site has more than 50 acres of gardens surrounded by a deer exclusion fence and 500 acres of natural land that provided a diverse community of local insects with which to evaluate insect herbivore preference among plants within the experimental garden.

We selected 10 common species of ornamental trees and shrubs native to the mid-Atlantic U.S. area that were available in the trade and also serve as host plants to a variety of common insects, particularly species of moths and butterflies (Lepidoptera) (Table 1). Thus, we evaluated the potential impact of six popular ornamental traits for our study: 1) red, purple, or blue leaf color expressed during the growing season; 2 ) variegated (white- and greenpatterned) leaf color; 3 ) plants with a growth habit modified to lowgrowing or compact forms; 4 ) disease resistance; 5 ) increased fruit size and yield; and 6) enhanced fall colors (i.e., color expressed only during fall leaf senescence). Each trait was represented in the study by three different species (three replicates). We paired the parent species (straight species) with its cultivar(s) (Table 1; Supplemental Figs. 1-10). Plants were grouped within the garden by species, with the straight species and its cultivar(s) adjacent to each other to facilitate insect choice of plants. Five individuals of each species or cultivar were spaced $4 \mathrm{ft}$ apart to allow for growth and to provide a larger target for herbivores to locate and populate.

Cultivars used in the growth habit comparisons differed from their straight species in the following ways. Eastern red cedar (Juniperus virginiana 'Gray Owl') is a prostrate selection that spreads but gets no taller than about $30 \mathrm{~cm}$. In comparison, the plants representing the straight species were $6 \mathrm{ft}$ tall in our study. Sweetgum (Liquidambar styraciflua'Slender
Silhouette') was the same size as the straight species (10 ft tall), but half as wide. Redosier dogwood (Cornus sericea 'Farrow') reached $3 \mathrm{ft}$ during our study whereas the straight species exceeded $6 \mathrm{ft}$.

After plantings were established, we allowed them to grow and become synchronized phenologically for 1 year before we sampled. Insects were sampled destructively once in June, July, and Aug. 2015 and 2016. This sampling regime covered seasonal shifts that drive insect abundance while preventing any excessive reduction of insect populations. Insects were collected via vacuum sampling (Brook et al., 2008) and the total search technique (Wagner, 2005). Samples were standardized by time allocated to sampling effort as a result of differences in size and growth pattern of plant species and cultivars. First we vacuumed plant foliage (30 s/sample) using a leaf blower (Craftsman gasoline blow/vac, item no. 7179469; Sears, Hoffman Estates, IL) in vacuum mode fitted with a 5-gal paint strainer bag (Burghardt et al., 2010). The bags were labeled and put into jars containing ethyl acetate to kill the insects. After collection, samples were labeled and stored in vials of $85 \%$ ethanol for later identification to the least possible taxonomic unit. We then searched leaves and stems of target plants

Table 1. Treatments, plant species, and cultivars compared with straight species in terms of insect herbivory (abundance, species richness, and cumulative seasonal damage) in a common garden as well as with feeding preference experiments using evergreen bagworm hatchlings.

\begin{tabular}{|c|c|c|c|}
\hline Trait & Common name & Cultivar name & Trade name \\
\hline \multirow[t]{2}{*}{ Red/purple colored leaf } & Eastern red cedar & CorCorCor & Emerald Sentinal \\
\hline & Arrowwood viburnum & NJ Select & Red Feather \\
\hline \multirow[t]{3}{*}{ Variegated leaf } & Flowering dogwood & Firecomz & Firebird \\
\hline & Sweetgum & Aurea & \\
\hline & Redosier dogwood & Silver and Gold & \\
\hline Growth habit & Eastern red cedar & Gray Owl & \\
\hline \multirow[t]{3}{*}{ Disease resistance } & American elm & Princeton & \\
\hline & Flowering dogwood & Appalachian Spring & \\
\hline & Redosier dogwood & Cardinal & \\
\hline Fruit size and yield & Highbush blueberry & Chandler & \\
\hline & Red maple & Franksred & Red Sunset \\
\hline
\end{tabular}

${ }^{\mathrm{z}}$ Jim Dandy male for pollination 
meticulously for 5 -min intervals for any caterpillars [larvae of moths, butterflies, and sawflies (Symphyta)] that had not been removed by vacuuming (Raimondo et al., 2004; Wagner, 2005). Gall and leaf mines were also counted and collected, if necessary for identification, during the 5-min search. Any caterpillars that could not be identified in the field were collected and laboratory reared on respective host plants until the adult stage or until identification could be achieved.

\section{Feeding preference trials}

To compare insect preference further for or against cultivars and their straight species, we used nochoice feeding trials (described later) to quantify leaf area consumed by the evergreen bagworm, a generalist lepidopteran species with host records on all of our study plants (Rhainds et al., 2009; Tallamy and Shropshire, 2009; Wagner, 2005). We chose nochoice tests because in most garden settings, insects do not have a choice between straight species and their cultivars; it is one or the other. In 2015 and 2016, leaves of each species and its cultivars were collected from our experimental garden after they had expanded to full size following budbreak in the spring. Female evergreen bagworms and their eggs never leave their protective bags; thus, we could collect eggs easily by collecting the overwintering bags. The bags of adult female evergreen bagworms were collected in mid May and were monitored in the laboratory for egg hatch. In 2015, evergreen bagworms hatched during the evening of 19 May and leaves were collected for the trials on 20 May. In 2016, evergreen bagworms hatched early in the morning or overnight on 4 June and leaves were collected for the trials the same day. We collected 20 leaves from each plant type (four extra to replace any ripped leaf disks) from southward-facing branches. Leaves were selected from the fifth branch from the ground or at breast height [depending on plant type/size (i.e., tree vs. small shrub)]. We removed four leaves from each of the five plants, carefully selecting leaves that would be large enough to allow us to cut leaf disks.

The experiment was conducted in $4 \times 4$-cell well trays (BAWl28; Bio-Serv,
Flemington, NJ) within a climatecontrolled laboratory. We cut 11.25mm-diameter leaf disks with a cork borer, being careful to avoid large veins that may have contained greater amounts of defensive compounds, and placed one leaf disk in each cell (16 replicates per plant type). For eastern red cedar, needles were flattened and cut with the cork borer so that just the bottoms of the wells were covered. Three evergreen bagworm larvae were placed gently on each leaf disk with a fine-tip paintbrush within hours of hatching. The wells were then covered with plastic well covers (Plastic 16 well covers for trays, part no. BACVl6; BioServ). Temperature was not controlled, but all larvae for each species-cultivar pair each year were reared simultaneously in the same place. After $48 \mathrm{~h}$, larvae were removed and leaf disks were placed into labeled vials containing wetted paper towels for rehydration. After the leaves were pliable, we used a grid slide and stereoscope to estimate the percent of each disk that was eaten. We halved areas of the disks that had surface feeding (feeding that did not go all the way through the leaf).

\section{Cumulative leaf damage comparison}

To compare cumulative seasonal use of cultivars and their parent species, we measured the feeding damage that had accumulated throughout the season on leaves collected from study species in Sept. 2015 and 2016. Leaves were selected from the fifth southward-facing branch from the ground or at breast height [depending on plant type/size (i.e., tree vs. small shrub)]. We removed all leaves from branch axil to terminal end, moving to the next branch up the trunk as needed until we had collected 20 leaves from each of the five plants. Leaves were placed in plastic resealable bags, labeled, and brought back to the laboratory. We scanned images of all leaves with a scanner (DocuMate 510; Xerox, Norwalk, CT) and then uploaded each image onto ImageJ public domain software version 1.x (National Institutes of Health, Washington, DC) to estimate the area (measured in square centimeters) of each leaf that had been eaten, using the precise tracing and measuring tools of the software. We omitted eastern red cedar from this comparison because of our inability to detect feeding damage on juniper foliage.

\section{Data Analysis}

COMMON GARDEN EXPERIMENT. Data were analyzed with JMP Pro software (version 13; SAS Institute, Cary, NC). We tested difference in means in insect herbivore abundance and species richness by comparing cultivars with straight species for each plant species within each treatment using paired Student's $t$ tests and reporting $t$ statistics.

FEEDING PREFERENCE TESTS. For each cultivar trait, we compared the mean percent of leaf disk eaten by evergreen bagworms using analysis of variance (ANOVA) reporting $\mathrm{F}$ ratios. For each test, we included the main effect of plant species (three species used for each trait type) and plant type (parent and cultivar) as well as the interaction between plant species and plant type. To test for the effects of plant type on each individual plant species, we used Tukey's honest significant difference (HSD) post hoc comparison using function Tukey's HSD and setting the family-wise confidence level to $0.95(\alpha=0.05)$. We conducted separate ANOVAs for each of the six traits (color, disease, fall, fruit, habit, and variegated) and for each year (2015 and 2016), for a total of 12 tests. If our interaction term was not significant $(P>0.05)$, we removed it and reran our model with only fixed effects included. Because our percentage data were not normally distributed, we used an arcsine transformation before analysis. All analyses were conducted in Program R 3.4.3 (R Core Team, 2017).

Seasonal FeEding Damage. Data were analyzed using JMP Pro software (version 13; SAS Institute). Area of leaf damage was compared for each straight species and respective cultivar (s) using paired $t$ tests. A series of two-way ANOVAs were also conducted to compare the main and interaction effects between plant species and trait on the amount of insect damage at the end of the season. Plant species included the three levels (three species used for each trait type) and trait consisted of two levels (parent and cultivar trait). The two-way ANOVAs were conducted for both years (2015 and 2016) and all six cultivar traits. A post hoc Tukey HSD 
was also conducted for each ANOVA. Two-tailed $t$ tests were used as well to test for mean differences between parent species and respective cultivars for each plant species.

\section{Results \\ Common garden experiment}

SPECIES RICHNESS. The average number of herbivore species collected on straight species and the related cultivars is shown in Fig. 1A for each trait tested. Cultivars in which green leaf color is altered to red, blue, or purple supported significantly fewer herbivore species than the parent species $\left[\mathrm{t}_{26}=3.14, P=0.002\right.$, where 26 is the degree of freedom (df)]. In contrast, cultivars with disease resistance $\left(\mathrm{t}_{26}=-1.99, P=0.03\right)$ and those with variegated leaves $\left(t_{26}=\right.$ $-5.04, P<0.0001)$ supported significantly more herbivore species than the straight species. Cultivars with a modified growth habit supported marginally more species than their parent species $\left(t_{26}=-1.38, P=\right.$ 0.09 ), whereas cultivars with enhanced fall color or fruit production did not differ in species richness from the parent species $\left(\mathrm{t}_{26}=0.59, P=\right.$ 0.56 and $\mathrm{t}_{26}=-0.82, P=0.42$ respectively).

TOTAL ABUNDANCE: IMMATURES PLUS ADULTS OF ALL SPECIES. The relative proportion of each family of insects collected on each straight species and its cultivar is presented in Supplemental Fig. 1. When adults and immatures are pooled, cultivars with altered leaf color, disease resistance, increased fruit production, and leaf variegation all differed significantly in total insect herbivore abundance from their parent species, but in no consistent pattern (Fig. 1B). As with species richness, cultivars with leaves that had been selected for red or purple coloration supported significantly fewer herbivorous insects than their parent species $\left(\mathrm{t}_{26}=3.18, P=\right.$ $0.002)$. In contrast, cultivars with enhanced disease resistant $\left(\mathrm{t}_{26}=\right.$ $-1.73, P=0.05)$, variegated leaves $\left(\mathrm{t}_{26}=-1.76, P=0.05\right)$, and enhanced fruiting supported significantly more herbivores than the parent species $\left(t_{26}=\right.$ $-1.94, P=0.03)$. Cultivars with enhanced fall color and a modified growth habit supported the same number of insect herbivores as their parent species $\left(\mathrm{t}_{26}=0.10, P=0.33 ; \mathrm{t}_{26}=-0.19, P=\right.$ 0.85 , respectively).
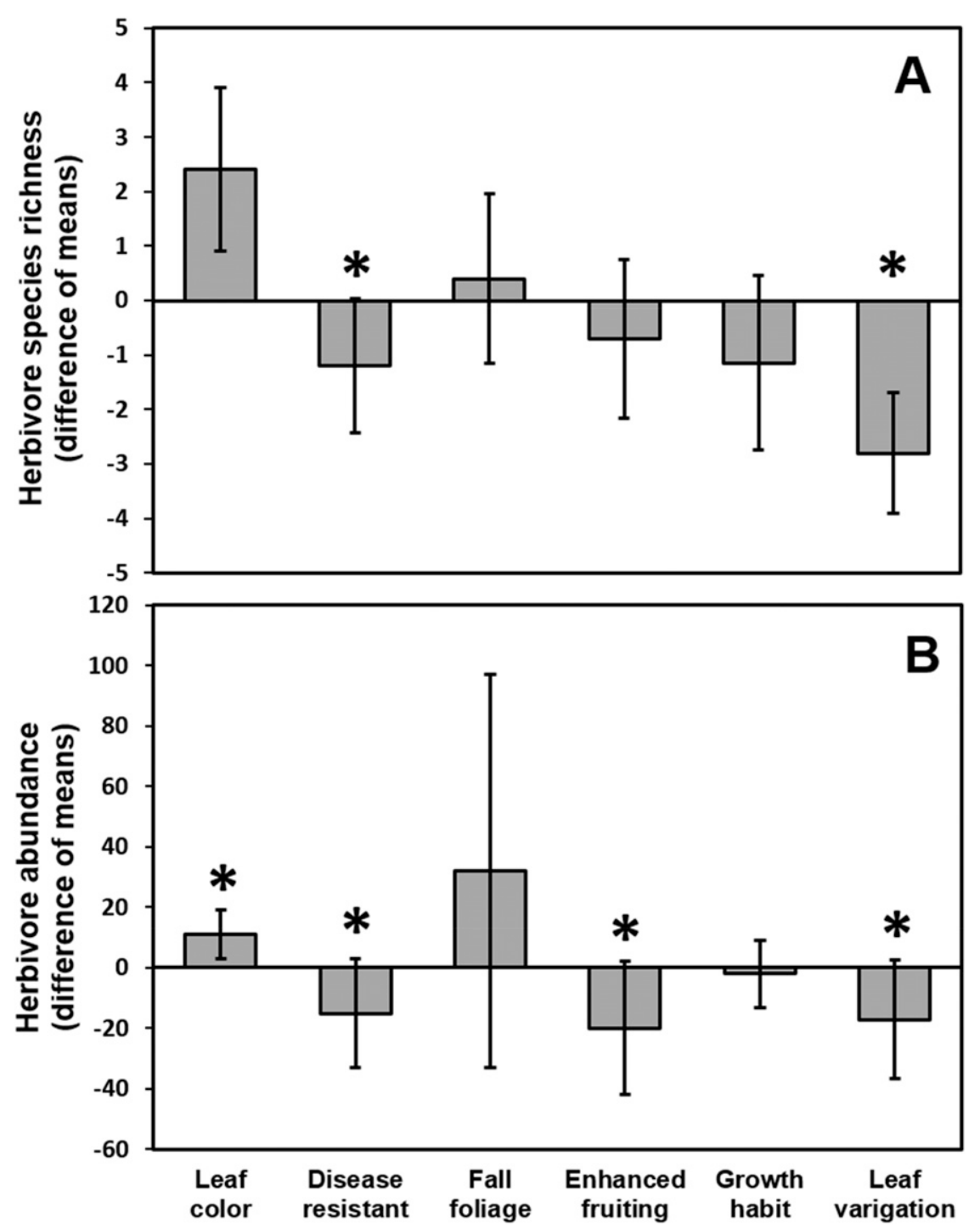

Fig. 1. Comparison of (A) average insect herbivore species richness and (B) abundance difference of means on straight species and their related cultivars using paired Student's $t$ tests. Cultivar traits examined include altered leaf color, disease resistance, enhanced fall color, enhanced fruiting, altered growth habit, and leaf variegation. Error bars $=95 \%$ confidence intervals; bars below zero have more species on cultivars; bars above zero have more species on straight species; * denotes significant differences at the $P<0.05$ level. Cultivars in which green leaf color is altered to red, blue, or purple supported significantly fewer herbivore species than the parent species $\left(t_{26}=3.14, P=0.002\right)$. In contrast, cultivars with disease resistance $\left(t_{26}=-1.99, P=0.03\right)$ and those with variegated leaves $\left(t_{26}=-5.04, P<0.0001\right)$ supported significantly more herbivore species than the straight species.

\section{Caterpillar species Richness} AND ABUNDANCE. As a result of their tendency to be host plant specialists, caterpillars were examined independently from other taxa. As with total abundance, there were significantly fewer caterpillar species on cultivars in which leaf color had been genetically altered to red, blue, or purple $\left[\mathrm{t}_{26}=2.41, P=0.01\right.$ (Fig. 2A) $]$ and significantly more caterpillar species on cultivars with variegated leaves $\left(t_{26}=-3.57, P=0.001\right)$. Contrary to the results that included adults of all insect species, cultivars with increased fruiting $\left(\mathrm{t}_{26}=0.45, P=0.66\right)$ and those with disease resistance $\left(\mathrm{t}_{26}=\right.$ $-0.74, P=0.47$ ) did not support more caterpillar species than their straight species. There were also no differences in the number of caterpillar species on cultivars with altered growth habits and cultivars with enhanced fall colors when compared 

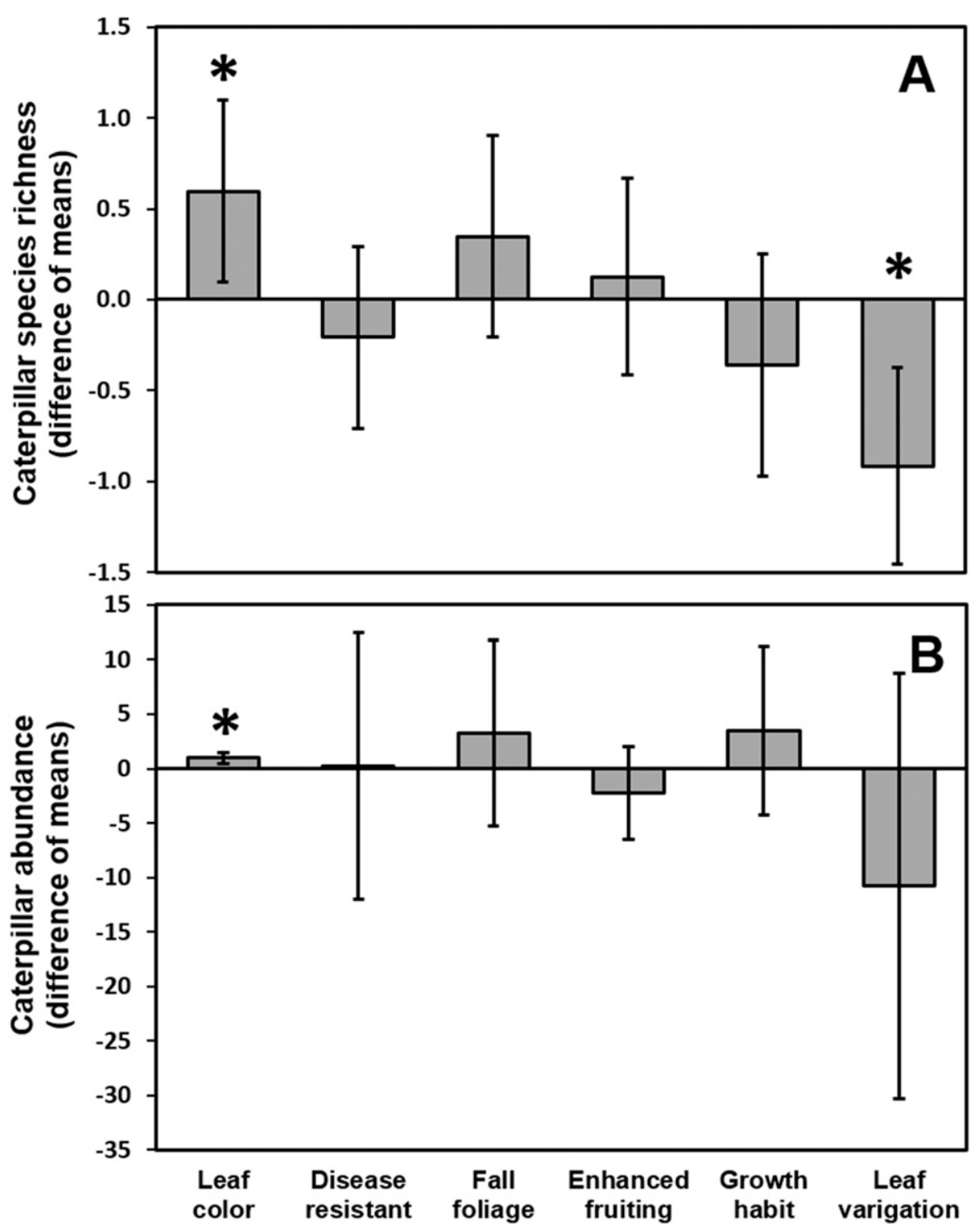

Fig. 2. Comparison of (A) average caterpillar species richness and (B) abundance difference of means using paired Student's $t$ tests. Cultivar traits examined include altered leaf color, disease resistance, enhanced fall color, enhanced fruiting, altered growth habit, and leaf variegation. Error bars $=\mathbf{9 5 \%}$ confidence intervals; bars below zero have more species on cultivars; bars above zero have more species on straight species; * denotes significant differences at the $P<0.05$ level. There were significantly fewer caterpillar species on cultivars in which leaf color had been genetically altered to red, blue, or purple $\left.\left[(A) t_{26}=2.41, P=0.01\right)\right]$ and significantly more caterpillar species on cultivars with variegated leaves $\left(\mathrm{t}_{26}=-3.57, P=0.001\right)$.

with their straight species (habit: $\mathrm{t}_{26}=-1.24, P=0.23$; fall color: $\mathrm{t}_{26}=$ $1.25, P=0.23)$.

Caterpillar abundance was also impacted variably by cultivar traits (Fig. 2B). Cultivars with red or purple leaves supported significantly fewer caterpillars than their green-leafed parents $\left(\mathrm{t}_{26}=3.04, P=0.003\right)$, but this trait was the only one that impacted caterpillar abundance significantly. Cultivars with enhanced disease resistance $\left(t_{26}=0.03\right.$, evergreen bagworm feeding significantly (plant type 2015: $\mathrm{F}_{1,90}=26.3$, $P<0.0001$, where 1 and 90 are the numerator and denominator df; plant type 2016: $\left.\mathrm{F}_{1,90}=34.7, P<0.0001\right)$. The interaction effect was significant in $2015\left(\mathrm{~F}_{2,90}=4.69, P=0.01\right)$, but not in $2016\left(\mathrm{~F}_{2,90}=2.32, P=0.10\right)$. Our Tukey comparison revealed that evergreen bagworm larvae fed less on cultivars of eastern red cedar (2015: difference $=-0.08, P=0.02 ; 2016$ : difference $=-0.15, P=0.001)$ and winged sumac $[R h u s$ copallinum (2015: difference $=-0.12, P<0.001$; 2016: difference $=-0.16, P<0.001)]$ in both years. There was no difference in the mean percent eaten for arrowwood viburnum (Viburnum dentatum) in either year (2015: difference $=-0.01$, $P=0.99 ; 2016$ : difference $=-0.06, P=$ $0.53)$.

LEAF VARIEgATION. Overall, there were significant differences between variegated cultivars (Fig. 3) in 2016 $\left(\mathrm{F}_{1,90}=9.23, P=0.003\right)$, but not in $2015\left(\mathrm{~F}_{1,90}=2.82, P=0.10\right)$. The interaction effect was significant in both $2015\left(\mathrm{~F}_{2,90}=6.85, P=0.001\right)$, and $2016\left(\mathrm{~F}_{2,90}=4.31, P=0.02\right)$. Evergreen bagworms ate significantly more of the sweetgum with variegated leaves than the parent genotype both years (2015: difference $=0.11, P=$ $0.003 ; 2016$ : difference $=0.15, P=$ $0.001)$. There were no differences between straight species and cultivar leaves in feeding amounts for flowering dogwood [Cornus florida (2015: difference $=0.02, P=0.99 ; 2016$ : difference $=0.00, P=0.99)]$ and redosier dogwood (2015: difference $=$ $-0.04, P=0.72 ; 2016$ : difference $=$ $0.05, P=0.73$ ).

ENHANCED FRUITING. The enhanced fruiting trait (Fig. 3) elicited no discernable pattern in feeding preference. There was no significant effect on feeding preference in either $2015\left(\mathrm{~F}_{1,90}=3.51, P=0.06\right)$ or 2016 $\left(\mathrm{F}_{1,90}=0.76, P=0.39\right)$; however, the interaction effect was significant in $2016\left(\mathrm{~F}_{2,90}=11.35, P<0.001\right)$. The cultivar of highbush blueberry (Vaccinium corymbosum) was eaten significantly more than the straight species in 2016 (difference $=0.17, P=$ 0.01 ) but not in 2015 (difference $=$ $0.05, P=0.20$ ). For winterberry (Ilex verticillata), the straight species was eaten more often than the cultivar in 2016 (difference $=-0.16, P=0.02$ ), but not in 2015 (difference $=0.01$, 

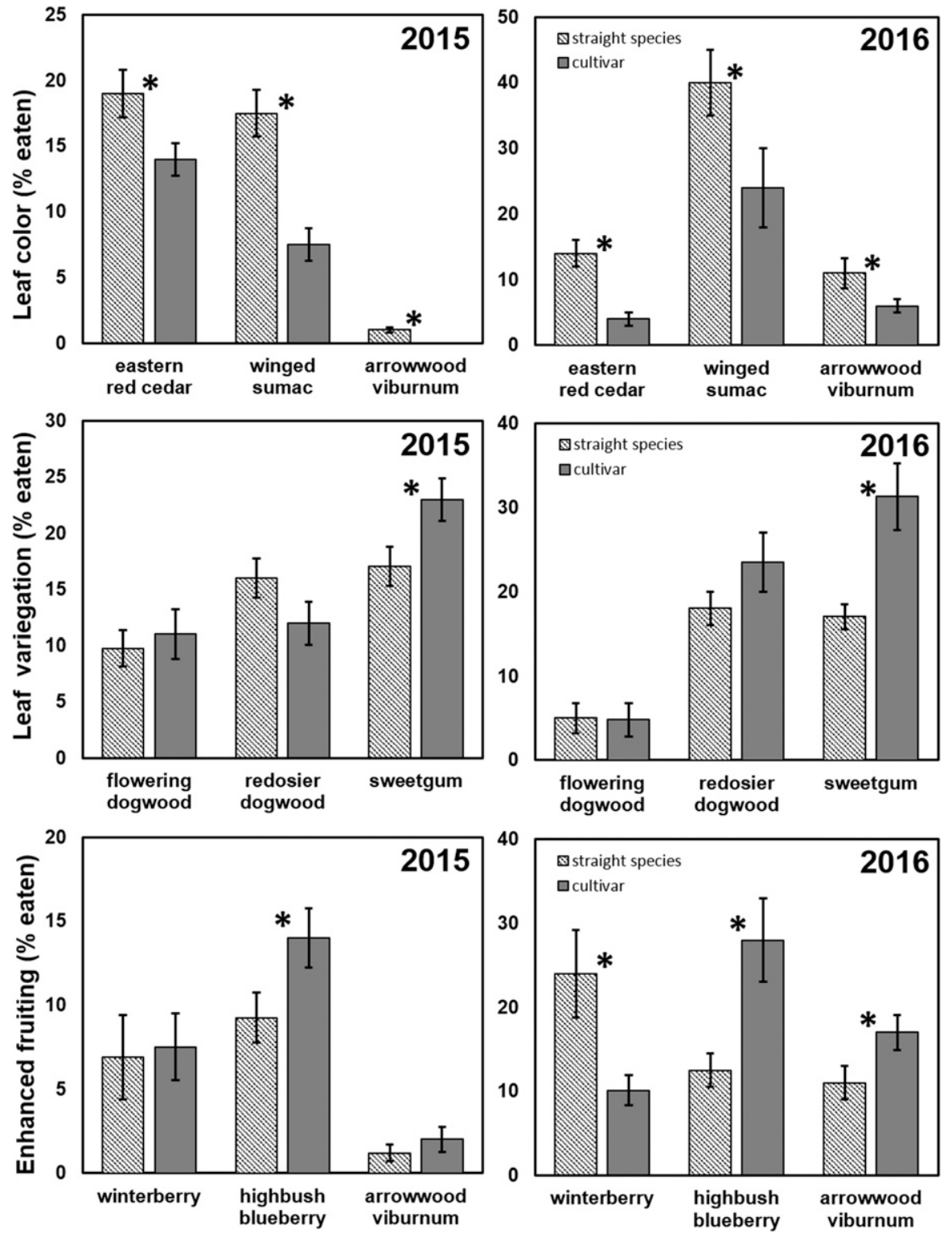

Fig. 3. Comparisons in 2015 and 2016 of hatchling evergreen bagworm feeding on leaf disks removed from straight species and cultivars of eastern red cedar, winged sumac, arrowwood viburnum, flowering dogwood, redosier dogwood, sweetgum, winterberry, and highbush blueberry with altered leaf color, leaf variegation, and enhanced fruiting. Leaves of each species and its cultivars were collected from a common experimental garden after they had expanded to full size following budbreak in the spring. For each cultivar trait, we compared the mean percent of leaf disk eaten by evergreen bagworms using analysis of variance in nochoice feeding preference trials. Error bars $=\mathrm{SE}$; * denotes significant differences at the $P<0.05$ level.

$P=0.99)$. There was no difference in feeding on arrowwood viburnum in either year $(2015$ : difference $=0.01$, $P=0.99 ; 2016$ : difference $=0.07, P=$ 0.77 ).

Disease Resistance. In general, disease resistance (Fig. 4) did not affect evergreen bagworm feeding when cultivars were compared with their straight species. Disease-resistant cultivars and controls did not differ in feeding amounts in $2015\left(\mathrm{~F}_{1,90}=\right.$ $0.06, P=0.81)$ and $2016\left(\mathrm{~F}_{190}=\right.$ $0.39, P=0.53)$. There was no difference in the percent feeding between the straight species and cultivar for flowering dogwood (2015: difference $=$ $0.04, P=0.77 ; 2016$ : difference $=$ $0.02, P=0.98)$, redosier dogwood (2015: difference $=-0.01, P=0.99$; 2016: difference $=0.02, P=0.99)$ or American elm (2015: difference $=-0.01$,
$P=0.99,2016:$ difference $=-0.07, P=$ $0.17)$.

FALL COLOR. Enhanced fall color (Fig. 4) did not, in general, affect evergreen bagworm feeding in either year. In 2015 and 2016, there were no differences between evergreen bagworm feeding on cultivars with enhanced fall foliage and on their parent plants $\left(2015: \mathrm{F}_{1,90}=1.54\right.$, $P=0.22 ; 2016: F_{1,90}=1.16, P=$ 0.28 ). However, there was a significant interaction between plant species and type in $2016\left(\mathrm{~F}_{2,90}=4.80, P=\right.$ $0.01)$. There was significantly less feeding on the red maple (Acer rubrum) cultivar than on the straight species in 2016 (difference $=-0.11$, $P=0.05$ ), but not in 2015 (difference $=$ $0.02, P=0.98$ ). There was no difference between plant types for redosier dogwood (2015: difference $=0.05, P=$ 0.57; 2016: difference $=0.05, P=$ $0.71)$ nor for arrowwood viburnum (2015: difference $=0.00, P=0.99$; 2016: difference $=-0.01, P=0.99$ ).

Growth HABIT. In general, growth habit (Fig. 4) did not affect evergreen bagworm feeding in either year $\left(2015: \mathrm{F}_{1,90}=0.00, P=0.95\right.$; 2016: $\left.\mathrm{F}_{1,90}=2.19, P=0.14\right)$; however, there was a significant interaction between plant species and plant type in $2016\left(\mathrm{~F}_{2,90}=6.98, P=\right.$ $0.001)$. There was significantly more feeding on the cultivar for sweetgum in 2016 (difference $=0.12, P=0.01$ ), but not in 2015 (difference $=-0.05$, $P=0.64)$. In either year, there was no difference in feeding on redosier dogwood (2015: difference $=0.05, P=$ $0.68 ; 2016$ : difference $=0.02, P=$ $0.99)$ nor on eastern red cedar $(2015$ : difference $=0.00, P=0.99 ; 2016$ : difference $=-0.05, P=0.56)$.

\section{Cumulative leaf damage}

Altered LeAF COLOR. As with insect sampling and feeding trials, altering leaf color (Fig. 5) from green to red or purple depressed insect herbivory significantly. Parent plants sustained significantly more feeding over the season than color-altered cultivars (2015: $\mathrm{F}_{1,5}=6.49, P=$ $0.01 ; 2016: \mathrm{F}_{1,5}=16.07, P<$ $0.0001)$. The interaction effect was significant in $2015\left(\mathrm{~F}_{1,5}=5.27\right.$, $P=0.02)$, but not in $2016\left(\mathrm{~F}_{1,5}=\right.$ $2.49, P=0.12$ ). Insects fed significantly less on red-leafed arrowwood viburnum cultivars than on parent plants both years $\left(2015: \mathrm{t}_{118}=-2.56, P=0.01\right.$; 

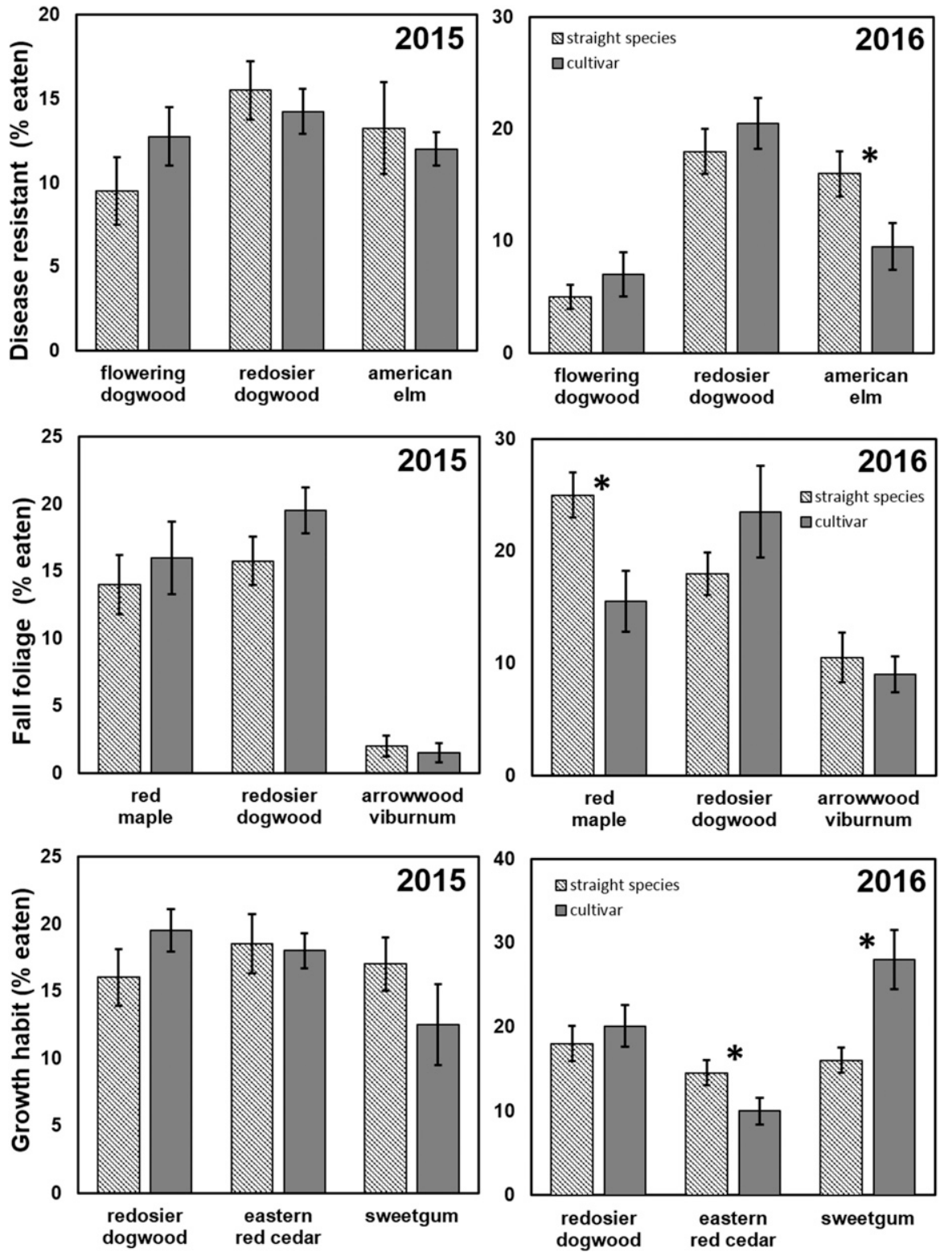

Fig. 4. Comparisons in 2015 and 2016 of hatchling evergreen bagworm feeding on leaf disks removed from straight species and cultivars of american elm, red maple, arrowwood viburnum, flowering dogwood, redosier dogwood, sweetgum, and eastern red cedar, with disease resistant, enhanced fall foliage and altered growth habit. Leaves of each species and its cultivars were collected from a common experimental garden after they had expanded to full size following budbreak in the spring. For each cultivar trait, we compared the mean percent of leaf disk eaten by evergreen bagworms using analysis of variance in no-choice feeding preference trials. Error bars $=\mathrm{SE} ;{ }^{*}$ denotes significant differences at the $P<0.05$ level.

2016: $\left.\mathrm{t}_{122}=-2.96, P=0.004\right)$. In 2015, there was no difference in seasonal insect feeding damage on winged sumac plants, but in 2016 the color-altered cultivars were eaten significantly less than the greenleafed straight species (2015: $\mathrm{t}_{198}=$ $-0.40, P=0.70 ; 2016: \mathrm{t}_{106}=-3.67$, $P=0.0004)$.

LEAF VARIEGATION. Variegation (Fig. 5) impacted feeding significantly only in both years but not in a consistent way. In 2015 and 2016, parent stock of redosier dogwood supported significantly more feeding than the variegated cultivars (2015: $\mathrm{t}_{111}=$ $-6.02, P<0.0001 ; 2016: \mathrm{t}_{131}=$ $-4.69, P<0.0001)$. In 2015 , flowering dogwood variegated cultivars had marginally less damage than the straight species $\left(\mathrm{t}_{111}=-1.91, P=\right.$ $0.06)$, and in 2016 there were no differences in feeding activity $\left(\mathrm{t}_{191}=\right.$ 1.71, $P=0.09$ ). Variegated cultivars of sweetgum had the same amount of feeding in 2015 as the straight species $\left(\mathrm{t}_{196}=-1.57, P=0.12\right)$, and in 2016 the cultivars had more feeding evidence than the straight species $\left(\mathrm{t}_{196}=\right.$ 2.04, $P=0.04)$.

ENHANCED FRUITING. There was no difference in cumulative insect feeding between cultivars with enhanced fruiting (Fig. 5) and their straight species in 2015 (winterberry: $\mathrm{t}_{195}=-1.84, P=0.07$; blueberry: $\mathrm{t}_{149}=$ 1.67, $P=0.10$; arrowwood viburnum: $\left.\mathrm{t}_{169}=0.16, P=0.90\right)$. In 2016, winterberry $\left(\mathrm{t}_{185}=2.63, P=0.01\right)$ and arrowwood viburnum $\left(\mathrm{t}_{126}=\right.$ $3.87, P=0.0002)$ had significantly more feeding damage on the leaves of their enhanced fruiting cultivars whereas there was no difference between cultivar and straight species for arrowwood viburnum $\left(\mathrm{t}_{187}=1.63\right.$, $P=0.11)$.

Disease resistance. The disease-resistant (Fig. 6) trait caused a significant effect $\left(\mathrm{F}_{1,5}=9.94, P=\right.$ 0.002 ), but again with no discernable pattern. Redosier dogwood parent plants supported significantly more cumulative feeding than the diseaseresistant cultivars in both years $(2015$ : $\mathrm{t}_{143}=-2.88, P=0.01 ; 2016: \mathrm{t}_{169}=$ $-3.33, P=0.001$ ), but there were no such differences between cultivars and straight species for American elm (Ulmus americana) in either year (2015: $\mathrm{t}_{159}=0.50, P=0.62 ; 2016$ : $\left.\mathrm{t}_{195}=-0.20, P=0.85\right)$. In 2015, flowering dogwood disease-resistant cultivars had significantly more feeding than their straight species, and in 2016 the straight species had more damage than the cultivars $\left(2015: \mathrm{t}_{177}=\right.$ $2.24, P=0.03 ; 2016: \mathrm{t}_{119}=-3.14, P=$ 0.002 ).

ENHANCED fall COLOR. There were significant differences between cultivars with enhanced fall foliage (Fig. 6) and their straight species in both years (2015: $\mathrm{F}_{1,5}=7.36, P=$ $\left.0.01 ; 2016: \mathrm{F}_{1,5}=12.90, P=0.02\right)$, although the interaction effect was significant only in $2016\left(\mathrm{~F}_{1,5}=3.96\right.$, $P=0.02$ ). In both 2015 and 2016, redosier dogwood straight species had significantly more evidence of leaf feeding than the cultivars with enhanced fall color (2015: $\mathrm{t}_{169}=-2.77$, $P=0.01 ; 2016: \mathrm{t}_{155}=-3.38, P=$ $0.001)$. There was no difference between straight species and cultivars on 

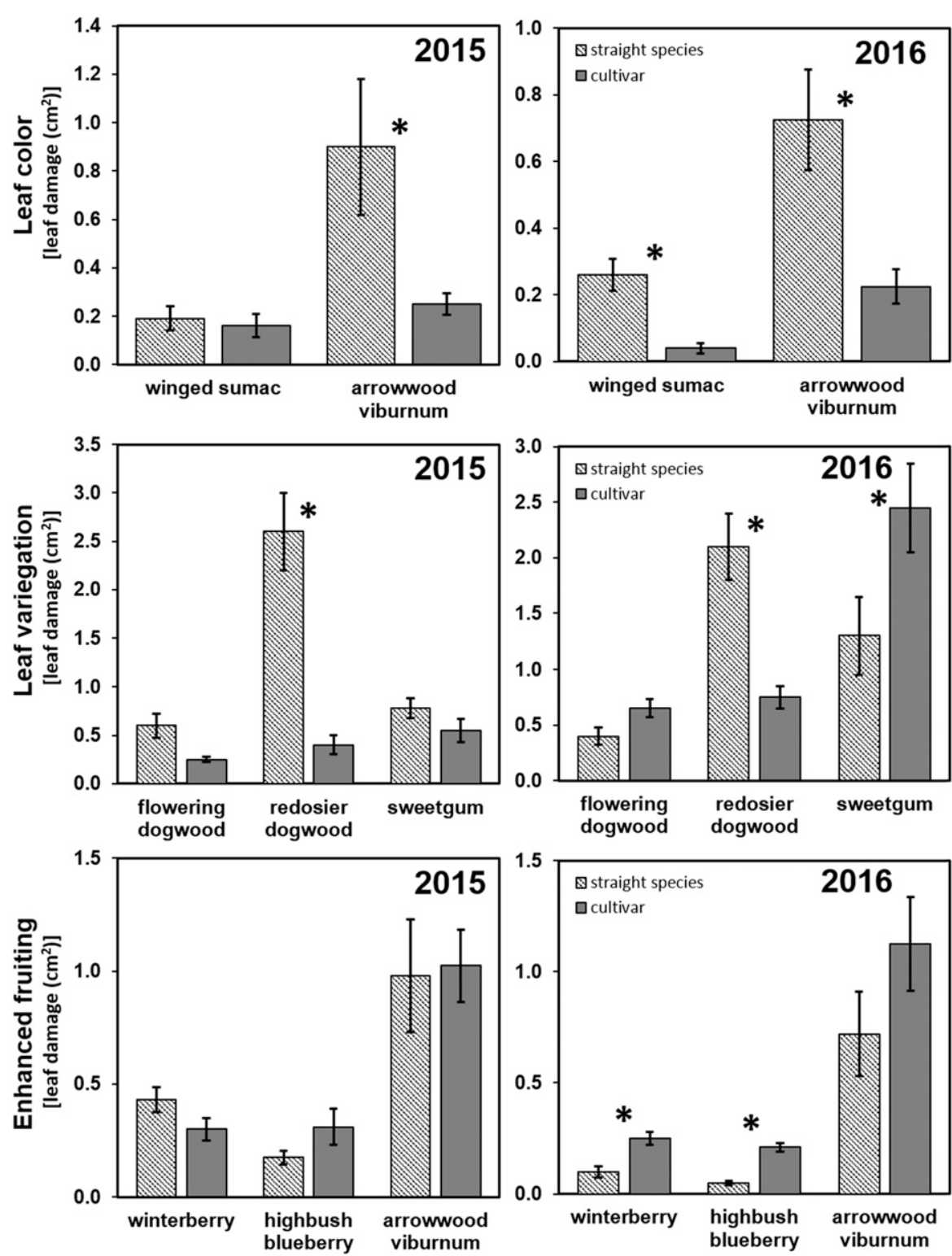

Fig. 5. Comparisons of seasonal cumulative leaf damage caused by insect herbivores on straight species and cultivars with altered leaf color, leaf variegation, and enhanced fruiting in both 2015 and 2016 using paired Student's $t$ tests. Error bars $=\mathrm{SE} ;{ }^{*}$ denotes significant differences at the $P<0.05$ level; $1 \mathrm{~cm}^{2}=0.1550$ inch $^{2}$.

red maple plants in 2015, but in 2016 there was significantly more feeding on the straight species compared with the cultivars $\left(2015: \mathrm{t}_{174}=-0.18, P=\right.$ $\left.0.9 ; 2016: \mathrm{t}_{190}=-2.04, P=0.04\right)$. Similarly, in 2015, arrowwood viburnum straight species had marginally more feeding than their cultivars, but in 2016 there was no difference between cultivars and straight species (2015: $\mathrm{t}_{141}=-1.93, P=0.06 ; 2016$ : $\left.\mathrm{t}_{192}=-0.33, P=0.74\right)$.

Altered growth habit. In general, creating cultivars with an altered growth habit (Fig. 6) did not impact insect feeding intensity in either year. Only redosier dogwood cultivars with altered growth habits differed from the straight species with significantly less insect damage in 2015 (redosier dogwood 2015: $\mathrm{t}_{142}=-3.47, P=$ $0.001 ; 2016: \mathrm{t}_{193}=0.25, P=0.80$; sweetgum 2015: $\mathrm{t}_{133}=1.86, P=$ $\left.0.07 ; 2016: \mathrm{t}_{191}=0.81, P=0.42\right)$.

\section{Discussion}

Our 2-year study of the ecologic value of native plant cultivars, examined by common garden comparisons of insect herbivory on cultivars and their straight species, as well as by laboratory no-choice feeding preference tests, yielded only one consistent result. Cultivars that are selected to change green leaves to red, blue, or purple, either throughout the season or during leaf senescence in the fall, significantly reduce insect herbivory three- to five-fold in one or more of our experiments. The other common cultivar traits we examined (disease resistance, altered growth habit, enhanced fruiting, and leaf variegation) occasionally caused significant differences in herbivory, but in no consistent or predictable pattern. In some cases, the straight species was used more than the cultivar, but in others, the cultivar was preferred or there was no difference in insect use.

Several hypotheses have been advanced to explain why leaves with pigments other than green chlorophyll are avoided by insect herbivores. Most plant pigments are secondary metabolic compounds that do not contribute to the growth of a plant, but often are distasteful to insects or impede protein assimilation and thus act as a defense against insect herbivory (Döring et al., 2009; Lev-Yadun and Gould, 2009; Manetas, 2006). It has also been proposed that the anthocyanins and carotenoids that cause red leaf coloration may signal the presence of defensive compounds and can deter insect herbivores before they even taste a leaf (Chen and Huang, 2013; Döring et al., 2009; Lev-Yadun and Gould, 2009; Schaefer and Rolshausen, 2006). Regardless of the mechanism, our data agree with earlier work (Schaefer and Wilkinson, 2004; War et al., 2012) suggesting that altering leaf color reduces insect use of a plant for growth and reproduction, and therefore such cultivars are not a good option when selecting plants to support insect-based food webs.

Because leaf variegation alters the chemical constituents of leaves, we expected cultivars with variegated leaves also to reduce insect use consistently, but this was not the case. In our common garden experiment, herbivore abundance and species richness as well as caterpillar species richness were all, on average, greater on variegated cultivars than on the straight species. Feeding preference and cumulative seasonal use results were not as clear. Although there was 

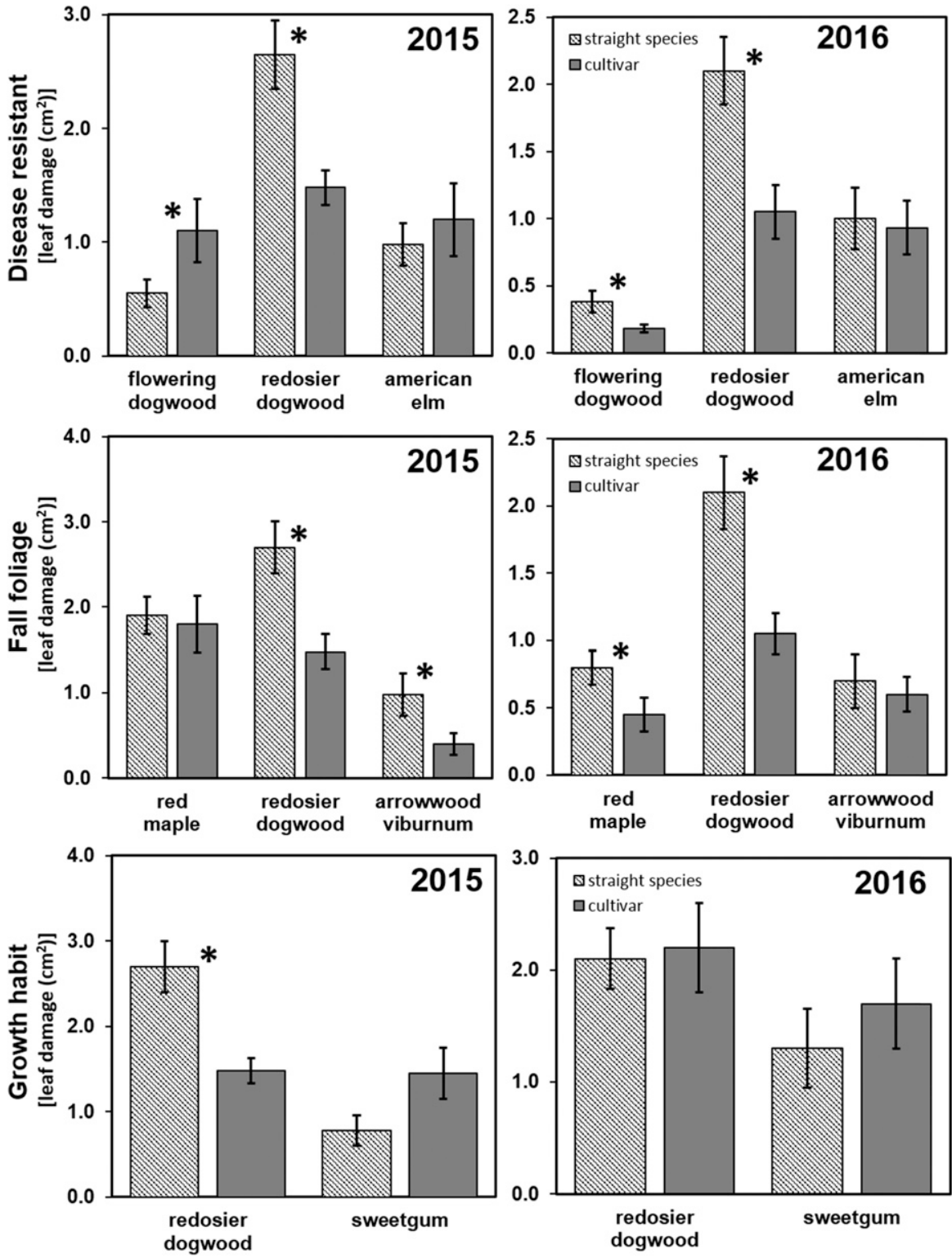

Fig. 6. Comparisons of seasonal cumulative leaf damage caused by insect herbivores on straight species and cultivars with disease resistance, enhanced fall foliage, and altered growth habits in both 2015 and 2016 using paired Student's $t$ tests. Error bars $=\mathrm{SE}$; * denotes significant differences at the $P<0.05$ level; $1 \mathrm{~cm}^{2}=$ 0.1550 inch $^{2}$.

an overall preference for sweetgum's variegated cultivar in feeding preference tests and seasonal use, there were no such preferences for flowering dogwood and redosier dogwood variegated cultivars. There was significantly more feeding damage on parent plants of redosier dogwood in the seasonal analysis, whereas the flowering dogwood parent plants had only marginally more seasonal use.

Leaf variegation occurs when local regions on the surface of the leaf have reduced chlorophyll, resulting in lightened patterns (Campitelli et al.,
2008; Smith, 1986). Studies of wild populations of naturally occurring leaf variegation have often shown a deterrence of herbivore feeding (Campitelli et al., 2008; Lev-Yadun, 2014; Lev-Yadun and Gould, 2009; Lev-Yadun et al., 2004; Smith, 1986; Soltau et al., 2009). With less chlorophyll in their leaves, variegated plants are predicted to have reduced photosynthetic abilities and therefore lower productivity and nutrition per unit area of leaf (Smith, 1986). Reduced nutritional value has actually been shown to stimulate feeding in insects so that they may compensate for what it missing in their diet by eating more leaf tissue (Awmack and Leather, 2002; Hochuli, 1996). Such compensation may account for the excess feeding found on some of the variegated cultivars in our plots. We emphasize, however, that we found no evidence that the loss of chlorophyll is correlated with an increase in phytochemical defenses (Holopainen et al., 2009 ) and thus feeding deterrence.

We also found no discernable pattern associated with insect herbivory and disease resistance in cultivars. Several previous studies examining vector-specific systems have shown a correlation between disease resistance in plants and insect deterrence. For example, tree pathogens are often spread by insect vectors such as the european bark beetle (Scolytus multistriatus) and the native elm bark beetle (Hylurgopinus rufipes) that spread dutch elm disease (DED; Ophiostoma ulmi) (Smalley and Guries, 1993). Some cultivars of asian elm (Ulmus parvifolia) are resistant to DED and black leaf spot (Diplocarpon rosae) and are simultaneously repellent to the elm leaf beetle (Xanthogaleruca luteola), an invasive defoliator (Smalley and Guries, 1993, 2000). The same association has been found in american elm cultivars that are DED resistant (Santamour and Bentz, 1995).

However, studies suggest that correlations between disease resistance and resistance to insect vectors do not always extend to insect herbivores not involved in vectoring plant disease. For example, Herbert et al. (2009) found that the crapemyrtle aphid (Sarucallis kabawaluokalani) had greater fitness on cultivars and hybrids resistant to powdery mildew (Podosphaera xanthii). Similarly, Chappell et al. (2012) found that disease resistance in a number of crapemyrtle cultivars (Lagerstroemia indica) did not deter feeding by flea beetles (Alticini) or japanese beetle (Popillia japonica), whereas Rieske et al. (2003) documented gypsy moth (Lymantria dispar) preference for disease-resistant cultivars of american chestnut (Castanea dentata).

Like these studies, our experiments also showed that disease resistance did not discourage all insect herbivores. There were no elm leaf beetles present in our study, but DED 
resistance did not diminish elm use by the other insects in our plots. Potter and Redmond (2013) also found that DED resistance in american elm did not always confer resistance to elm specialists other than elm leaf beetle. Similarly, resistance to dogwood anthracnose (Discula destructiva) did not deter herbivorous insects consistently in our study. If this proves to be a general phenomenon, it could have important implications for conservation efforts that seek to use productive native species such as elms and dogwoods that have been previously compromised by the introduction of a disease. If disease-resistant plants can deter the disease agent and/or vector without deterring other insect herbivores important to food web diversity, it would give disease-resistant cultivars an important role in designed landscapes.

\section{Conclusions}

Our investigation of the ecologic value of woody plant cultivars in supporting insect herbivores important in urban food webs showed that only selections with anthocyaninenriched leaves reduced insect herbivory consistently compared with straight species. We found no evidence that enhanced fruiting, leaf variegation, disease resistance, and altered growth habit degrade insect-based food webs where such plants are grown. These results might guide plant breeders to produce fewer cultivars with red or purple leaf color to meet the needs of homeowners, park managers, and landscape designers interested in building landscapes with unquestioned food web value in the future.

\section{Literature cited}

American Society of Landscape Architects. 2017. Demand high for sustainable, tech-friendly residential landscapes. 15 Mar. 2018. <https://www.asla.org/ NewsReleaseDetails.aspx $?$ id $=50027>$.

Awmack, C.S. and S.R. Leather. 2002. Host plant quality and fecundity in herbivorous insects. Annu. Rev. Entomol. 47:817-844.

Brook, A.J., B.A. Woodcock, M. Sinka, and A.J. Vanbergen. 2008. Experimental verification of suction sampler capture efficiency in grasslands of differing vegetation height and structure. J. Appl. Ecol. 45:1357-1363.
Brzuszeki, R.F. and R.L. Harkess. 2009. Green industry survey of native plant marketing in the southeastern United States. HortTechnology 19:168-172.

Burghardt, K.T., D.W. Tallamy, C. Philips, and K.J. Shropshire. 2010. Non-native plants reduce abundance, richness, and host specialization in lepidopteran communities. Ecosphere 1:1-22.

Burghardt, K.T., D.W. Tallamy, and W.G. Shriver. 2008. Impact of native plants on bird and butterfly biodiversity in suburban landscapes. Conserv. Biol. 23:219224.

Campitelli, B.E., I. Stehlik, and J.R. Stinchcombe. 2008. Leaf variegation is associated with reduced herbivore damage in Hydrophyllum virginianum. Botany $86: 306-313$.

Chappell, M.R., S.K. Braman, J. WilliamsWoodward, and G. Knox. 2012. Optimizing plant health and pest management of Lagerstroemia spp. in commercial production and landscape situations in the southeastern United States: A review. J. Environ. Hort. 30:161-172.

Chen, Y.Z. and S.Q. Huang. 2013. Red young leaves have less mechanical defense than green young leaves. Oikos 122: 1035-1041.

Coombs, G. and D. Gilchrist. 2017. Native and invasive plants sold by the midAtlantic nursery industry: A baseline for future comparisons. 17 Feb. 2018. $<$ https://mtcubacenter.org/action/ nurserysurvey $/>$.

DeCandido, R., A.A. Muir, and M.B. Garguillo. 2004. A first approximation of the historical and extant vascular flora of New York City: Implications for native plant species conservation. J. Torrey Bot. Soc. 131:243-251.

Dolan, R.W., M.E. Moore, and J.D. Stephens. 2011. Documenting effects of urbanization on flora using herbarium records. J. Ecol. 99:1055-1062.

Döring, T.F., M. Archetti, and J. Hardie. 2009. Autumn leaves seen through herbivore eyes. Proc. Biol. Sci. 276:121-127.

Fowler, J. 2016. Specialist bees of the Northeast: Host plants and habitat conservation. Northeast. Nat. (Steuben) 23:305-320

Herbert, J.J., R.F. Mizell, III, and H.J. McAuslane. 2009. Host preference of the crapemyrtle aphid (Hemiptera: Aphididae) and host suitability of crapemyrtle cultivars. Environ. Entomol. 38:1155-1160.

Hochuli, D.F. 1996. The ecology of plant/insect interactions: Implications of digestive strategy for feeding by phytophagous insects. Oikos 75:133-141.
Holopainen, J.K., G. Semiz, and J.D. Blande. 2009. Life-history strategies affect aphid preference for yellowing leaves. Biol. Lett. 5:603-605.

Lev-Yadun, S. 2014. Potential defense from herbivory by 'dazzle effects' and 'trickery coloration' of leaf variegation. Biol. J. Linnaean Soc. 111:692-697.

Lev-Yadun, S., A. Dafni, M.A. Flaishman, M. Inbar, I. Izhaki, G. Katzir, and G. Ne'eman. 2004. Plant coloration undermines herbivorous insect camouflage. BioEssays 26:1126-1130.

Lev-Yadun, S. and K.S. Gould. 2009. Role of anthocyanins in plant defense, p. 22-28. In: C. Winefield, K. Davies, and K. Gould (eds.). Anthocyanins. Springer, New York, NY.

Manetas, Y. 2006. Why some leaves are anthocyanic and why most anthocyanic leaves are red? Flora 201:163-177.

McKinney, M.L. 2006. Urbanization as a major cause of biotic homogenization. Biol. Conserv. 127:247-260.

McKinney, M.L. 2008. Effects of urbanization on species richness: A review of plants and animals. Urban Ecosyst. 11:161-176.

Narango, D.L., D.W. Tallamy, and P.P. Marra. 2017. Native plants improve breeding and foraging habitat for an insectivorous bird. Biol. Conserv. 213:4250 .

Pearse, I.S., D.J. Harris, R. Karban, and A. Sih. 2013. Predicting novel herbivoreplant interactions. Oikos 122:15541564 .

Peterson, R.T. 1980. A field guide to the birds. Houghton Mifflin, Boston, MA.

Potter, D.A. and C.T. Redmond. 2013. Relative resistance or susceptibility of landscape-suitable elms (Ulmus spp.) to multiple insect pests. Arboricult. Urban For. 39:236-243.

Qian, H. and R.E. Rickleffs. 2006. The role of exotic species in homogenizing the North American flora. Ecol. Lett. 9:12931298.

R Core Team. 2017. R: A language and environment for statistical computing. 30 Mar. 2018. <https://www.R-project. $\operatorname{org} />$.

Raimondo, S., J.S. Strazanac, and L. Butler. 2004. Comparison of sampling techniques used in studying Lepidoptera population dynamics. Environ. Entomol. 33:418-425.

Rhainds, M., D.R. Davis, and P.W. Price. 2009. Bionomics of bagworms (Lepidoptera: Psychidae). Annu. Rev. Entomol. 54:209-226. 


\section{Research Reports}

Rieske, L.K., C.C. Rhoades, and S.P. Miller. 2003. Foliar chemistry and gypsy moth, Lymantria dispar (L.), herbivory on pure American chestnut, Castanea dentata (Fam: Fagaceae), and a disease-resistant hybrid. Environ. Entomol. 32:359-365.

Salisbury, A., J. Armitage, H. Bostock, J. Perry, M. Tatchell, and K. Thompson. 2015. Enhancing gardens as habitats for flower-visiting aerial insects (pollinators): Should we plant native or exotic species? J. Appl. Ecol. 52:1156-1164.

Santamour, F.S., Jr. and S.E. Bentz. 1995. Updated checklist of elm (Ulmus) cultivars for use in North America. J. Arboric. 21:122-131.

Schaefer, M.H. and G. Rolshausen. 2006. Plants on red alert: Do insects pay attention? BioEssays 28:65-71.
Schaefer, M.H. and D.M. Wilkinson. 2004. Red leaves, insects and coevolution: A red herring? Trends Ecol. Evol. 19:616-618.

Smalley, E.B. and R.P. Guries. 1993 Breeding elms for resistance to Dutch elm disease. Annu. Rev. Phytopathol. 31:325354.

Smalley, E.B. and R.P. Guries. 2000 Asian elms: Sources of disease and insect resistance, p. 215-230. In: C.P. Dunn (ed.). The elms. Springer, Boston, MA.

Smith, A.P. 1986. Ecology of leaf color polymorphism in a tropical forest species: Habitat segregation and herbivory. Oecologia 69:283-287.

Soltau, U., S. Dötterl, and S. LiedeSchumann. 2009. Leaf variegation in Caladium steudneriifolium (Araceae): A case of mimicry? Evol. Ecol. 23:503-512.
Standley, L.A. 2003. Flora of Needham, Massachusetts: 100 Years of floristic change. Rhodora 105:354-378.

Tallamy, D.W. 2017. Creating living landscapes: Why we need to increase plant/insect linkages in designed landscapes. HortTechnology 27:446-452.

Tallamy, D.W. and K.J. Shropshire. 2009. Ranking lepidopteran use of native versus introduced plants. Conserv. Biol. 23:941947.

Wagner, D.L. 2005. Caterpillars of eastern North America. Princeton Univ. Press, Princeton, NJ.

War, A.R., M.G. Paulraj, T. Ahmad, A.A. Buhroo, B. Hussain, S. Ignacimuthu, and H.C. Sharma. 2012. Mechanisms of plant defense against insect herbivores. Plant Signal. Behav. 7:1306-1320. 
Supplemental Table 1. Common names of families reported in Supplemental Figs. 1-18.

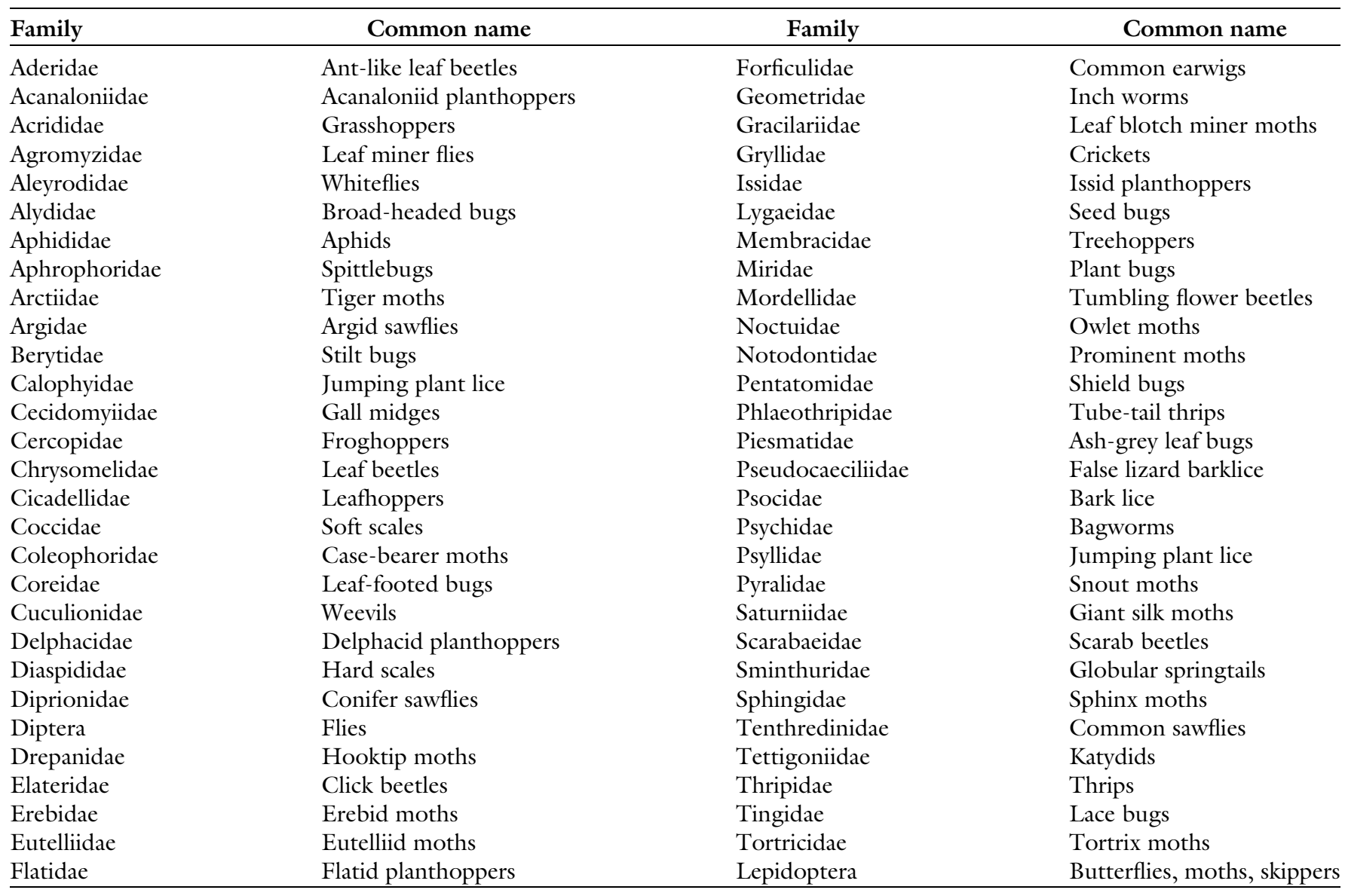
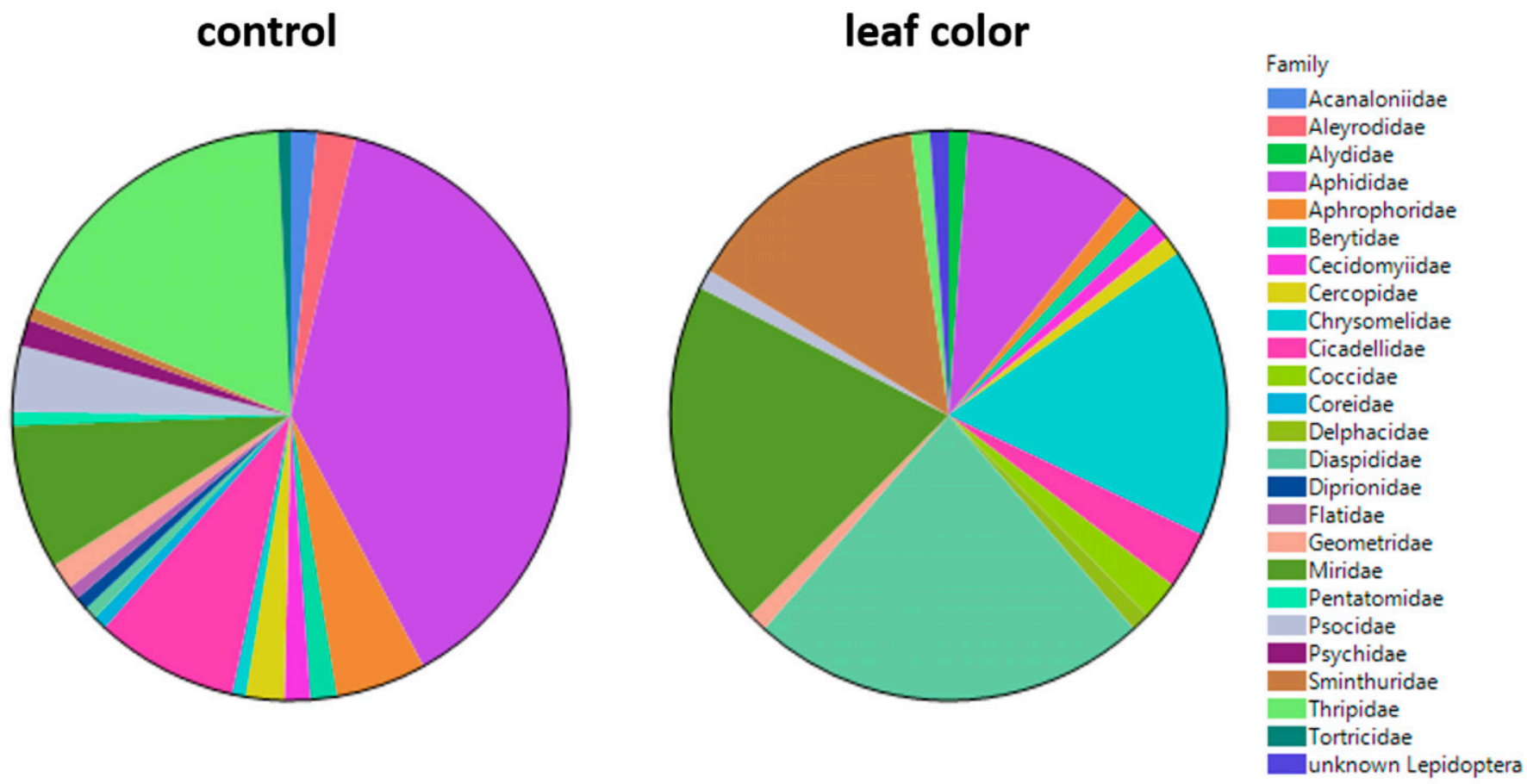

\section{Eastern red cedar}

Supplemental Fig. 1. Eastern red cedar insect family comparisons pie chart; altered leaf color cultivar and straight species. 31.6 \% similarity. (See Supplemental Table 1 for common names of families.) 

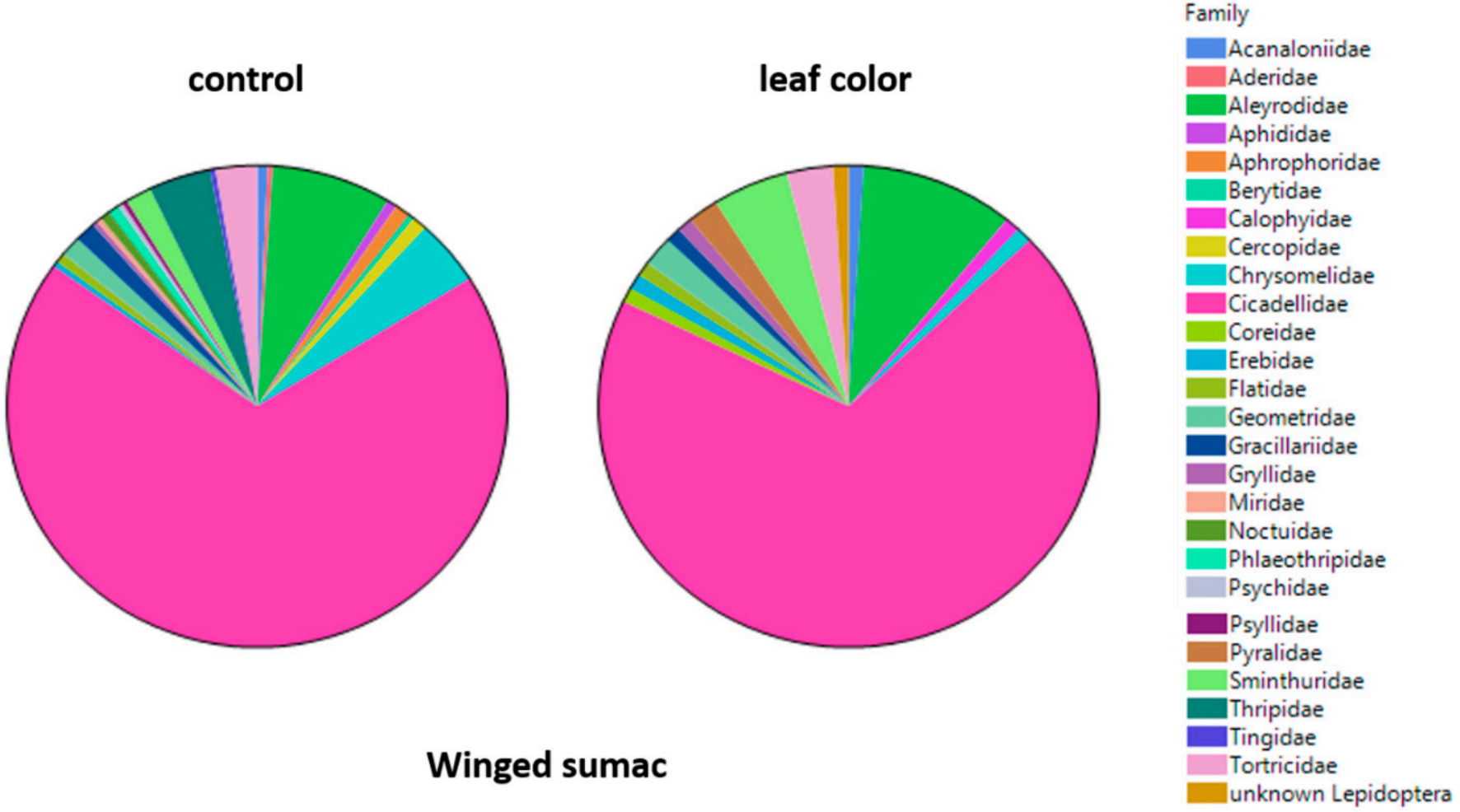

Family

Supplemental Fig. 2. Winged sumac insect family comparisons pie chart; altered leaf color cultivar and straight species. $86.2 \%$ similarity. (See Supplemental Table 1 for common names of families.)
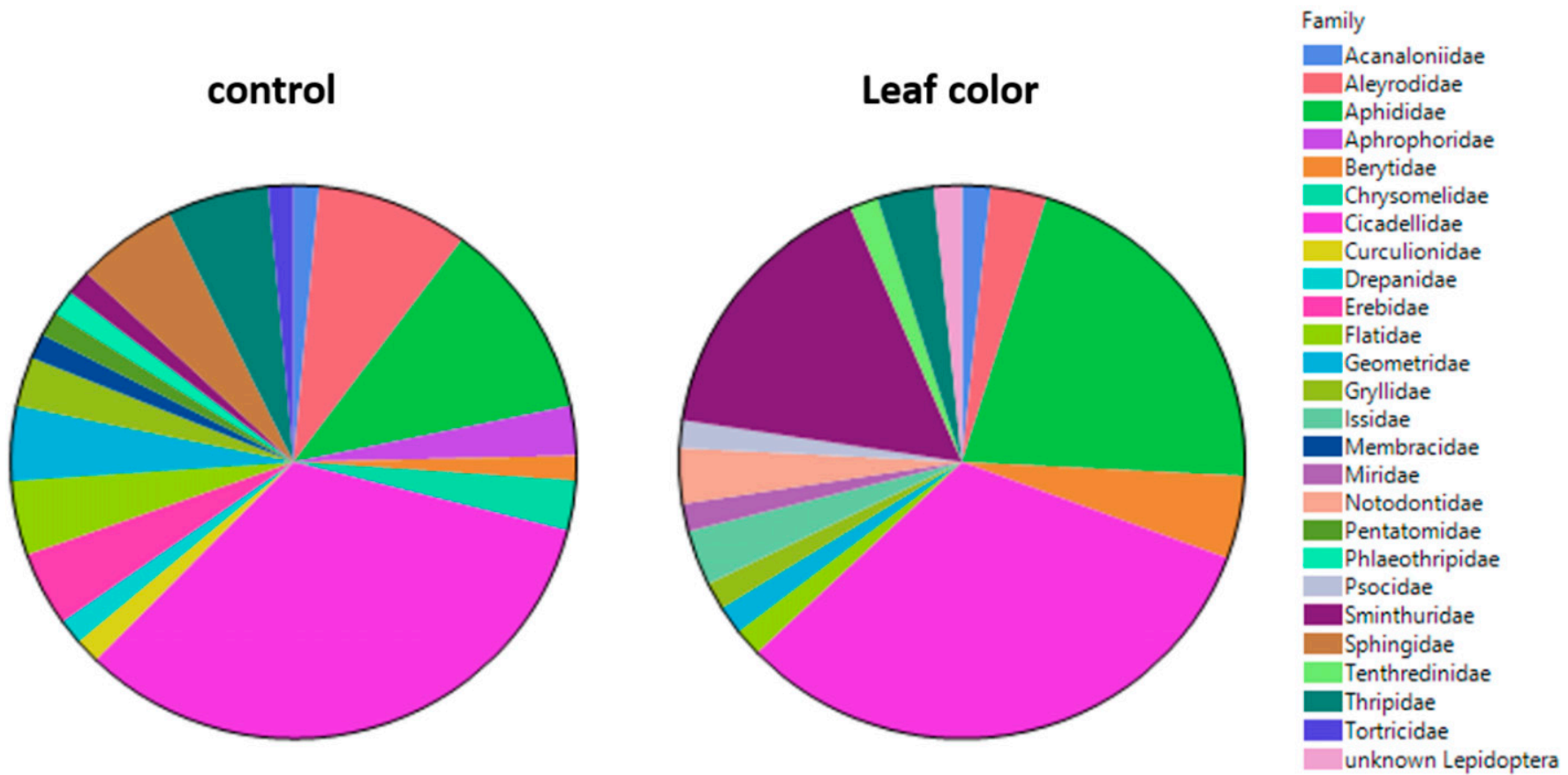

\section{Arrowwood viburnum}

Supplemental Fig. 3. Arrowwood viburnum insect family comparisons pie chart; altered leaf color cultivar and straight species. $59.6 \%$ similarity. (See Supplemental Table 1 for common names of families.) 


\section{control \\ leaf variegation}
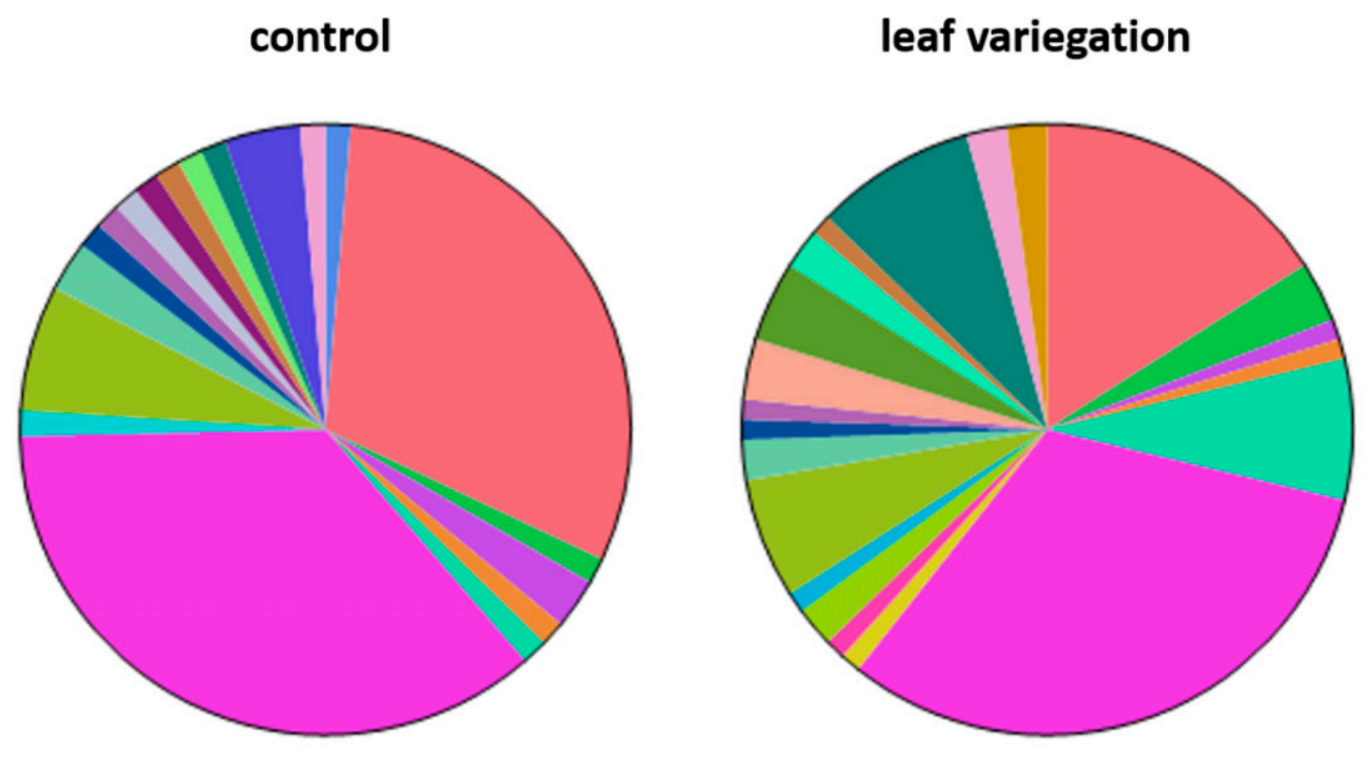

Flowering dogwood

Family

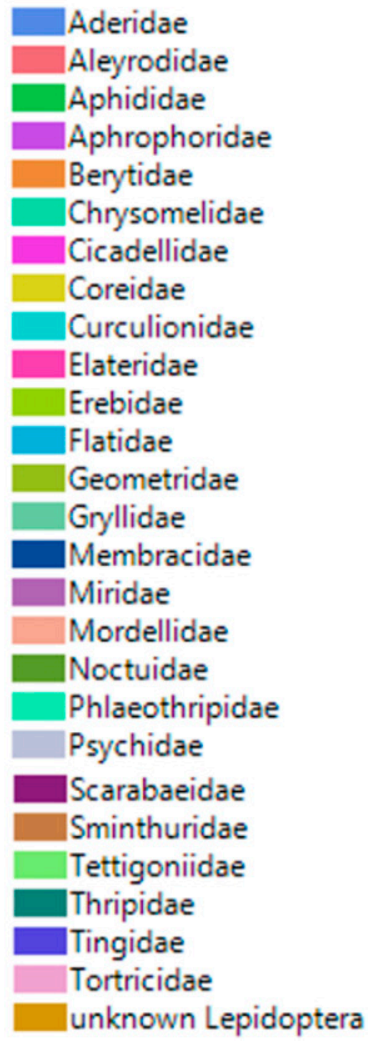

Supplemental Fig. 4. Flowering dogwood insect family comparisons pie chart; variegated cultivar and straight species. $67.0 \%$ similarity. (See Supplemental Table 1 for common names of families.)

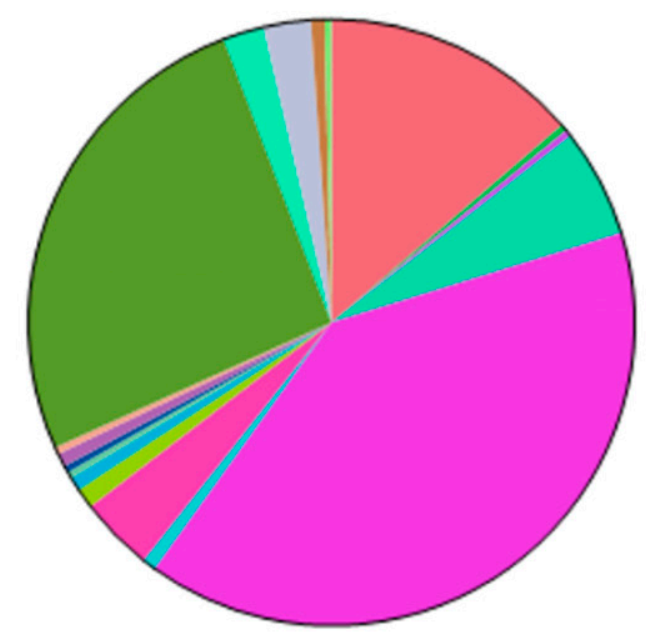

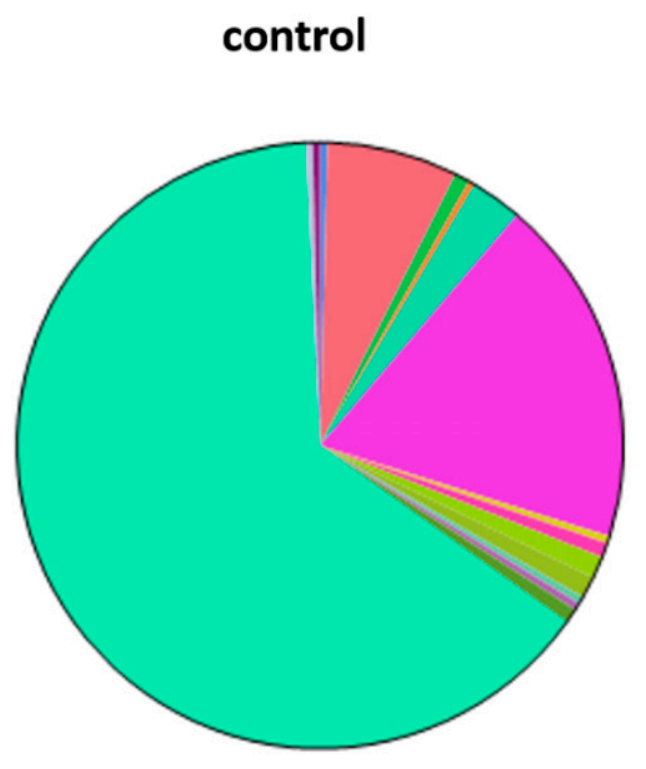

\section{Redosier dogwood}

leaf variegation similarity. (See Supplemental Table 1 for common names of families.)

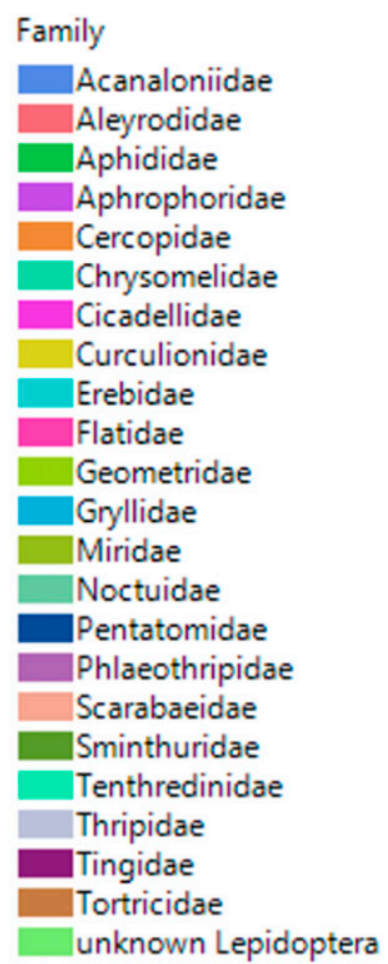

Supplemental Fig. 5. Redosier dogwood insect family comparisons pie chart; variegated cultivar and straight species. $34.6 \%$ 


\section{control}

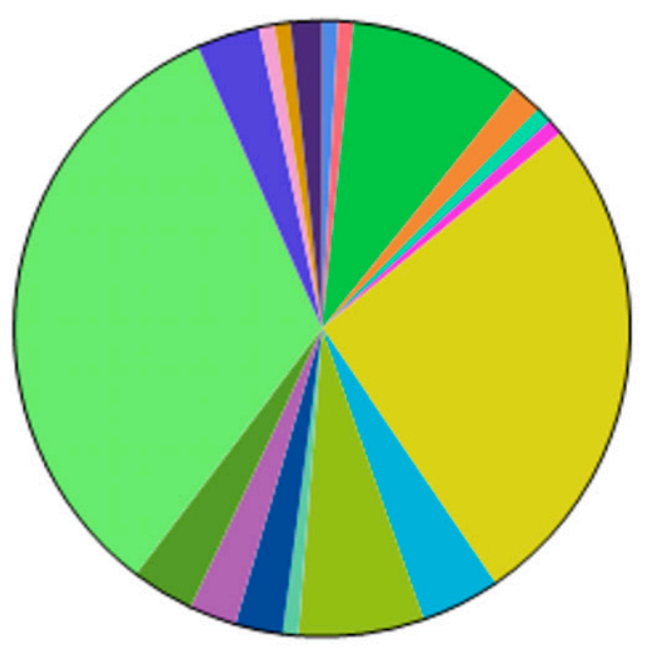

\section{leaf variegation}

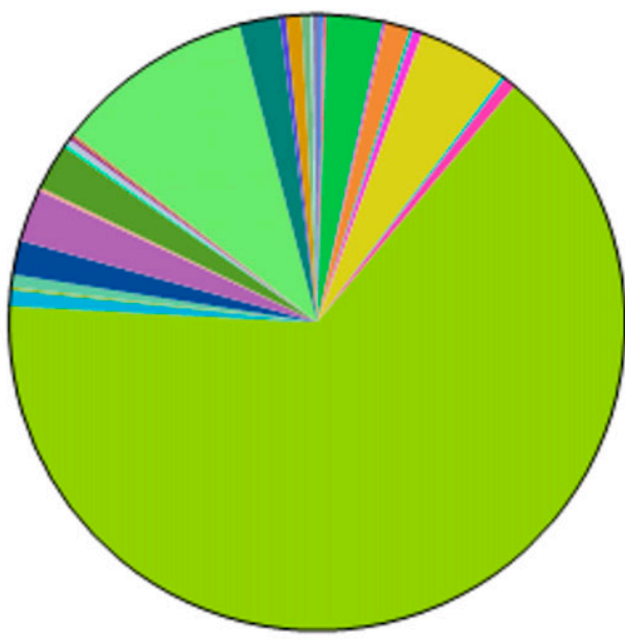

\section{Sweetgum} Supplemental Fig. 6. Sweetgum insect family comparisons p
(See Supplemental Table 1 for common names of families.)

Family

\begin{tabular}{|l}
\hline Acanaloniidae \\
\hline Aderidae \\
Aleyrodidae \\
\hline Aphididae \\
Aphrophoridae \\
Berytidae \\
Chrysomelidae \\
Cicadellidae \\
Coleophoridae \\
Elateridae \\
Erebidae \\
Euteliidae \\
Flatidae \\
Geometridae \\
Gryllidae \\
Membracidae \\
Noctuidae \\
\hline Phlaeothripidae \\
Pseudocaeciliidae \\
Psocidae \\
Psychidae \\
Psyllidae \\
Pyralidae \\
Saturniidae \\
\hline Sminthuridae \\
Tenthredinidae \\
Thripidae \\
Tingidae \\
Tortricidae \\
unknown Lepidoptera \\
\hline
\end{tabular}




\section{control}

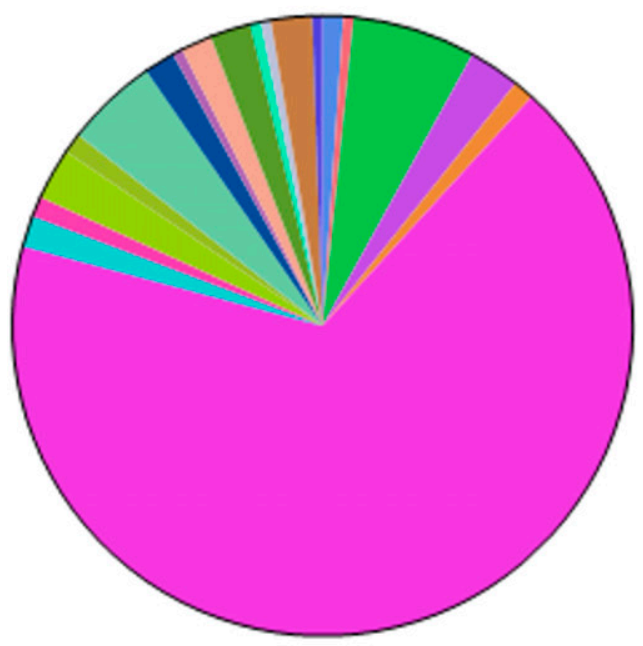

\section{enhanced fruiting}

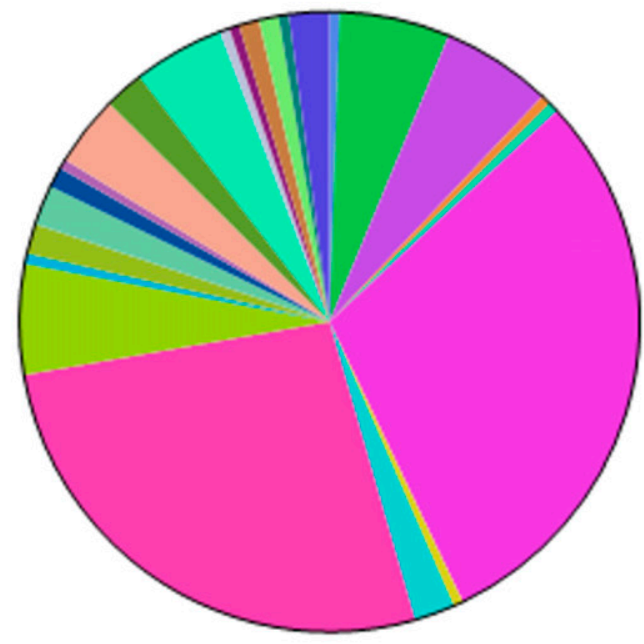

\section{Winterberry}

Supplemental Fig. 7. Winterberry insect family comparisons pie chart; enhanced fruiting cultivar and straight species. $56.0 \%$ similarity. (See Supplemental Table 1 for common names of families.) 


\section{Research Reports}
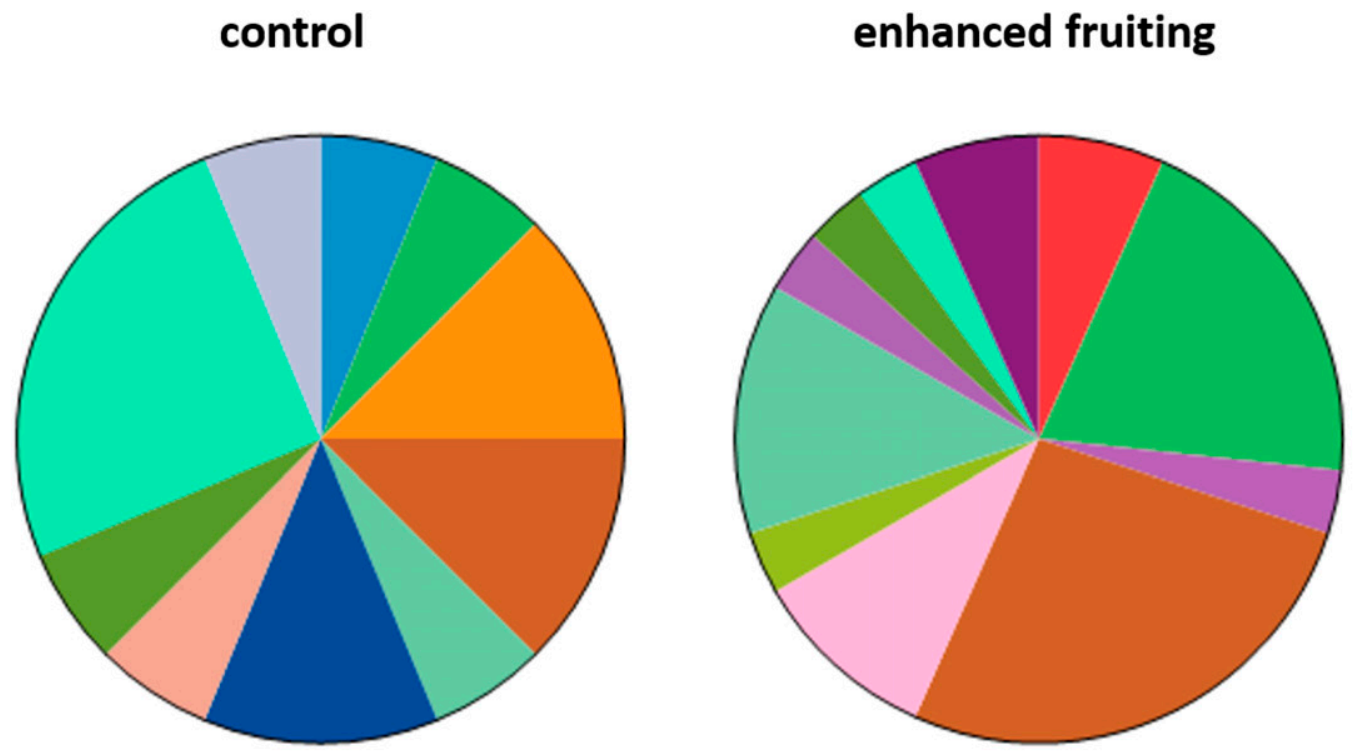

Family

\begin{tabular}{|l}
\hline Acanaloniidae \\
\hline Aleyrodidae \\
Aphididae \\
\hline Berytidae \\
\hline Chrysomelidae \\
\hline Cicadellidae \\
Geometridae \\
Gryllidae \\
Miridae \\
\hline Notodontidae \\
\hline Psocidae \\
Psychidae \\
\hline Thripidae \\
Tortricidae \\
unknown Diptera \\
unknown Lepidoptera
\end{tabular}

\section{Highbush blueberry}

Supplemental Fig. 8. Highbush blueberry insect family comparisons pie chart; enhanced fruiting cultivar and straight species. $31.7 \%$ similarity. (See Supplemental Table 1 for common names of families.)

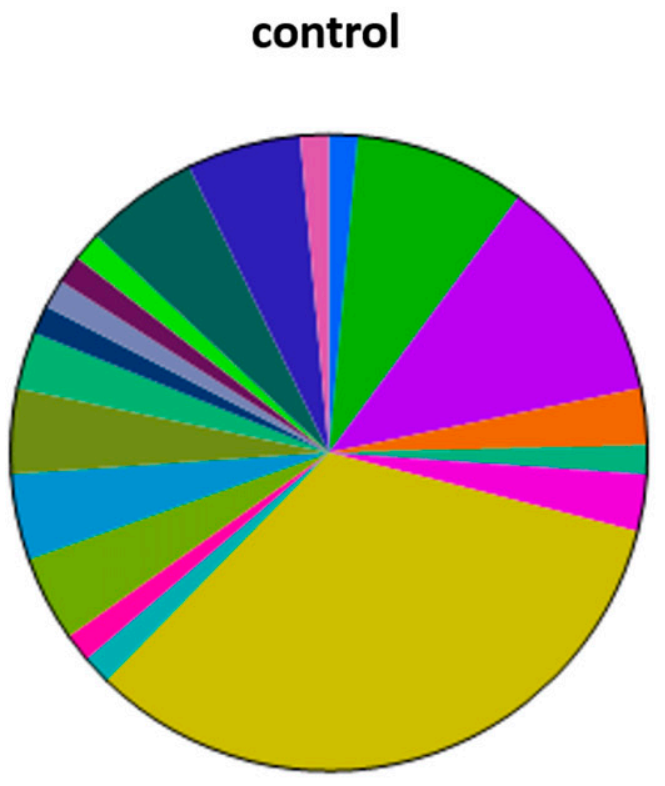

\section{enhanced fruiting}

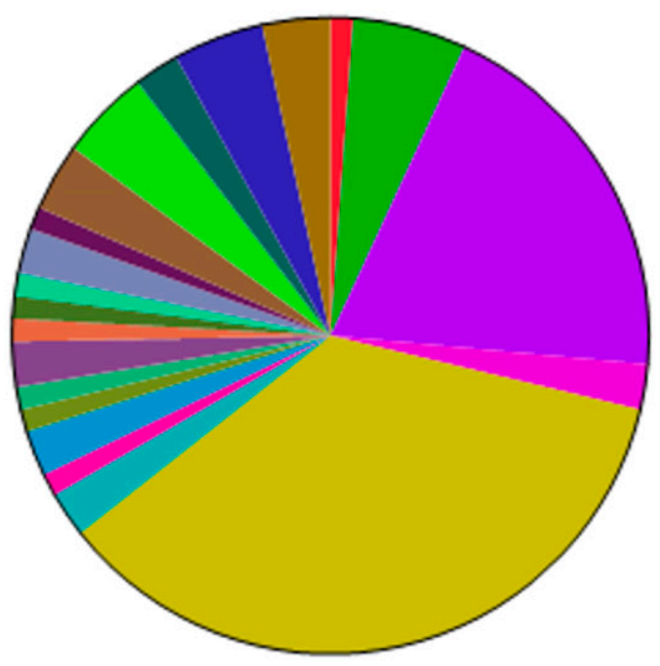

Arrowwood viburnum
Family

Acanaloniidae

Aderidae

Aleyrodidae

Aphididae

Aphrophoridae

Berytidae

Chrysomelidae

Cicadellidae

Curculionidae

Drepanidae

Erebidae

Flatidae

Geometridae

Gryllidae

Membracidae

Miridae

Mordellidae

Noctuidae

Notodontidae

Pentatomidae

Phlaeothripidae

Psocidae

Sminthuridae

Sphingidae

Thripidae

Tortricidae

unknown leaftier

Supplemental Fig. 9. Arrowwood viburnum insect family comparisons pie chart; enhanced fruiting cultivar and straight species. $71.8 \%$ similarity. (See Supplemental Table 1 for common names of families.) 


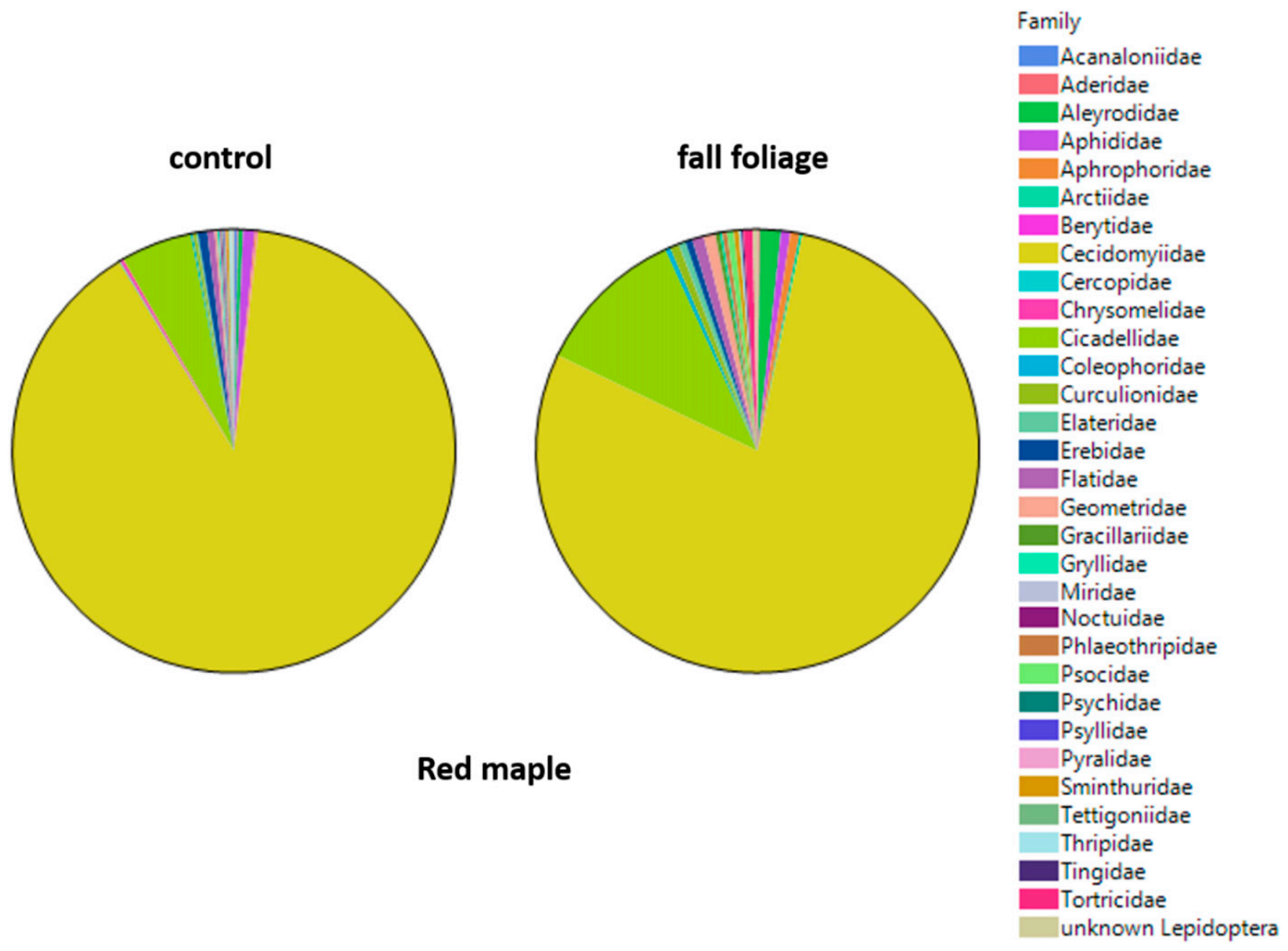

Supplemental Fig. 10. Red maple insect family comparisons pie chart; enhanced fall foliage cultivar and straight species. 88.0 \% similarity. (See Supplemental Table 1 for common names of families.) 


\section{Research Reports}

\section{control}

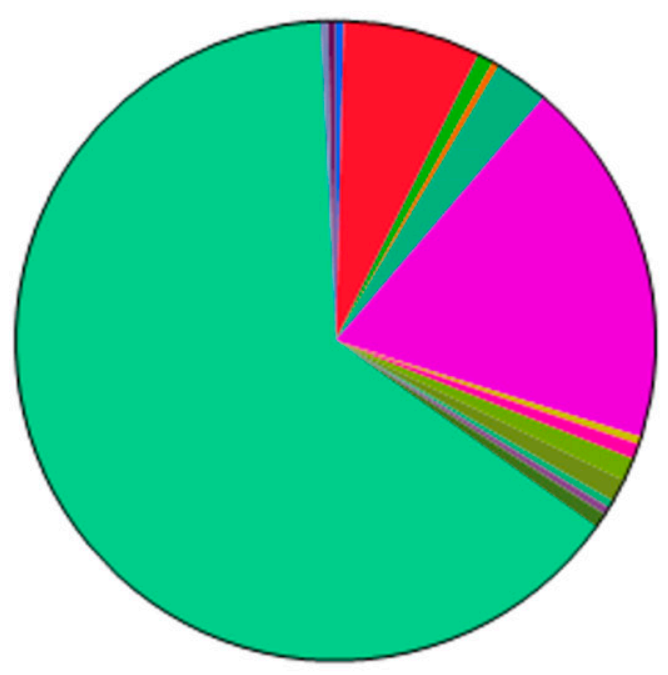

fall foliage

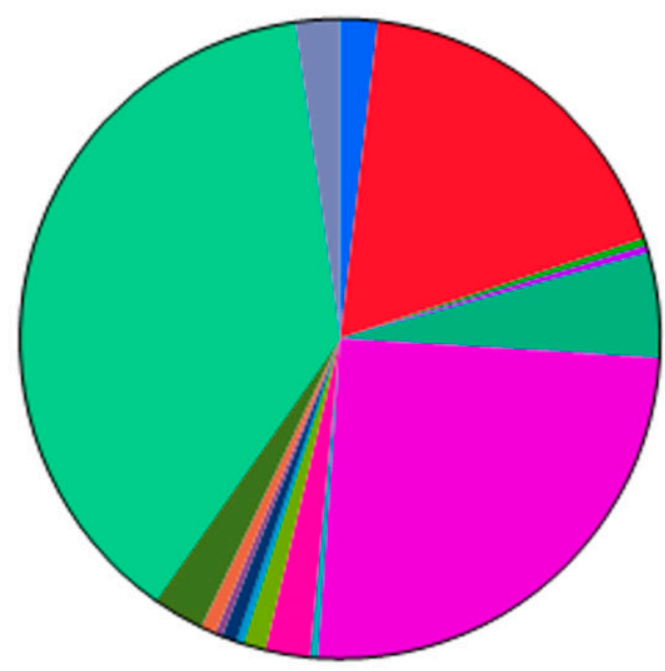

Family

\begin{tabular}{l} 
Acanaloniidae \\
\hline Aleyrodidae \\
Aphididae \\
Berytidae \\
Cercopidae \\
Chrysomelidae \\
Cicadellidae \\
Curculionidae \\
Erebidae \\
Flatidae \\
Geometridae \\
Gryllidae \\
Miridae \\
Noctuidae \\
Pentatomidae \\
Phlaeothripidae \\
Psocidae \\
Sminthuridae \\
Tenthredinidae \\
Thripidae \\
Tingidae
\end{tabular}

\section{Redosier dogwood}

Supplemental Fig. 11. Redosier dogwood insect family comparisons pie chart; enhanced fall foliage cultivar and straight species. $70.5 \%$ similarity. (See Supplemental Table 1 for common names of families.)

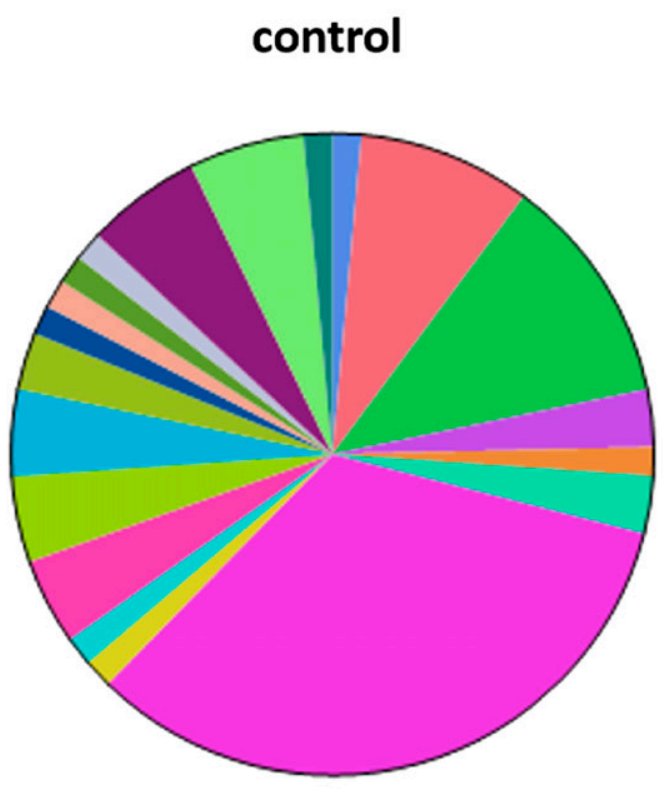

\section{fall foliage}

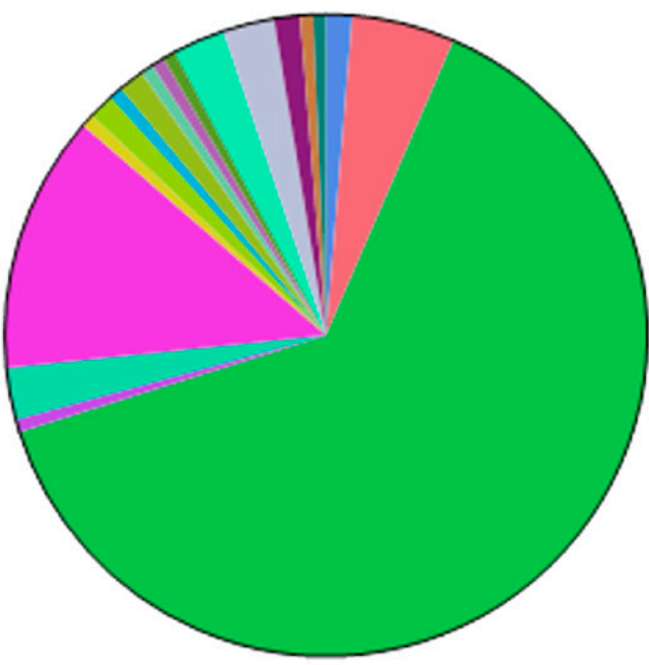

\section{Arrowwood viburnum}

Family

Acanaloniidae
Aleyrodidae
Aphididae
Aphrophoridae
Berytidae
Chrysomelidae
Cicadellidae
Curculionidae
Drepanidae
Erebidae
Flatidae
Geometridae
Gryllidae
Issidae
Membracidae
Miridae
Pentatomidae
Phlaeothripidae
Psocidae
Sminthuridae
Sphingidae
Tenthredinidae
Thripidae
Tortricidae

Supplemental Fig. 12. Arrowwood viburnum insect family comparisons pie chart; enhanced fall foliage cultivar and straight species. $\mathbf{4 2 . 4} \%$ similarity. (See Supplemental Table 1 for common names of families.) 
Family

\section{control}

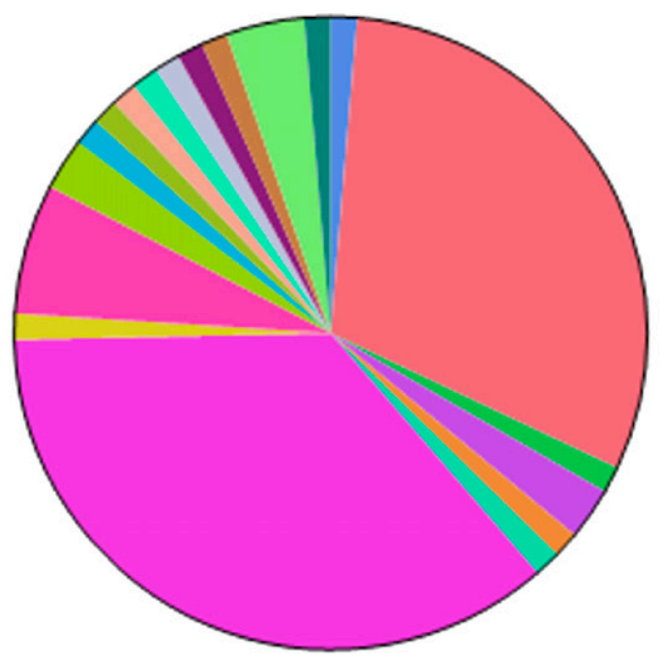

\section{disease resistant}

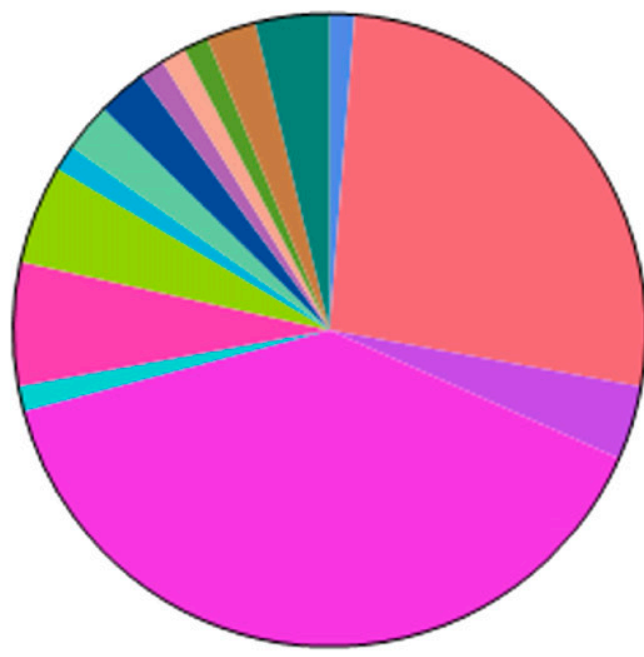

\section{Flowering dogwood}

Supplemental Fig. 13. Flowering dogwood insect family comparisons pie chart; disease resistant cultivar and straight species. $\mathbf{8 0 . 8} \%$ similarity. (See Supplemental Table 1 for common names of families.)
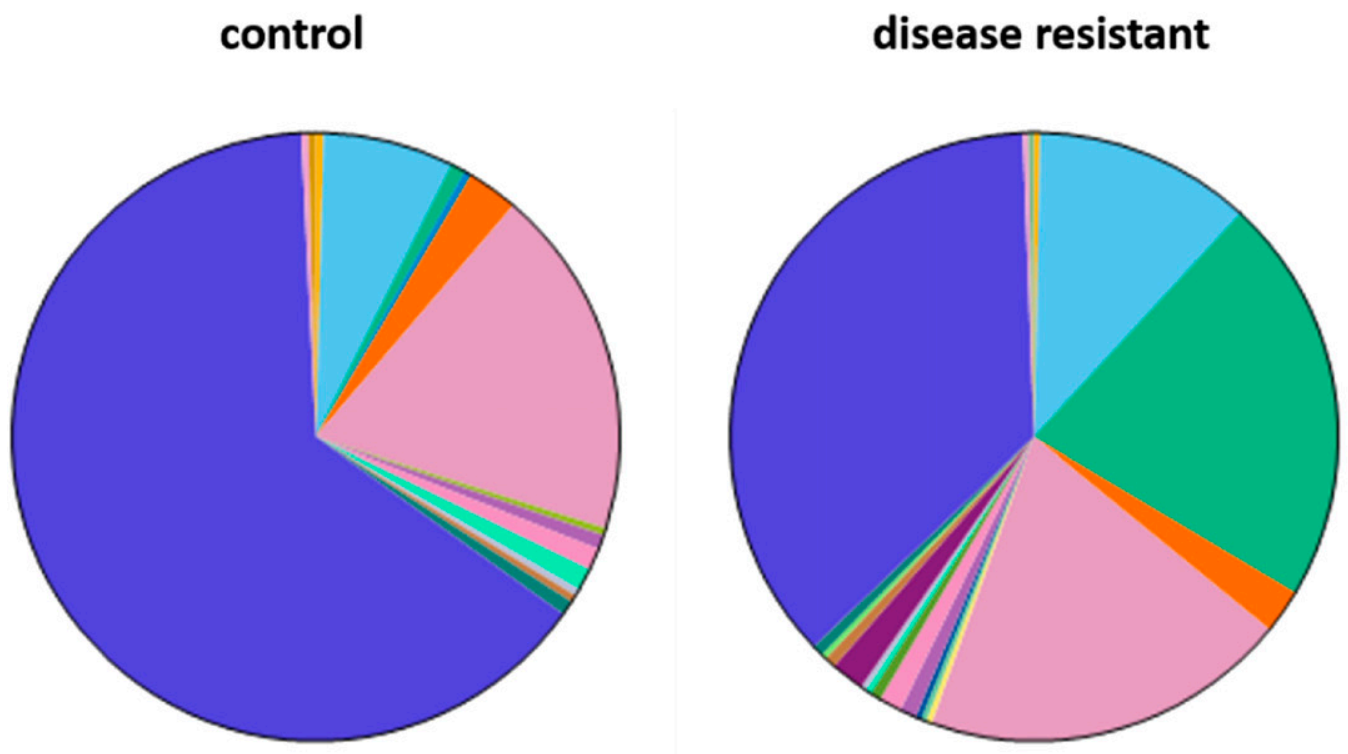

\section{Redosier dogwood}

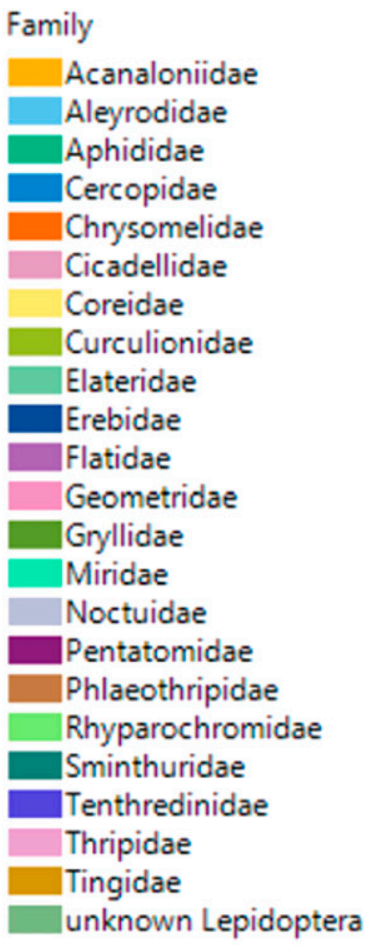

Supplemental Fig. 14. Redosier dogwood insect family comparisons pie chart; disease resistant cultivar and straight species. $\mathbf{6 9 . 4} \%$ similarity. (See Supplemental Table 1 for common names of families.) 


\section{Research Reports}

\section{control}

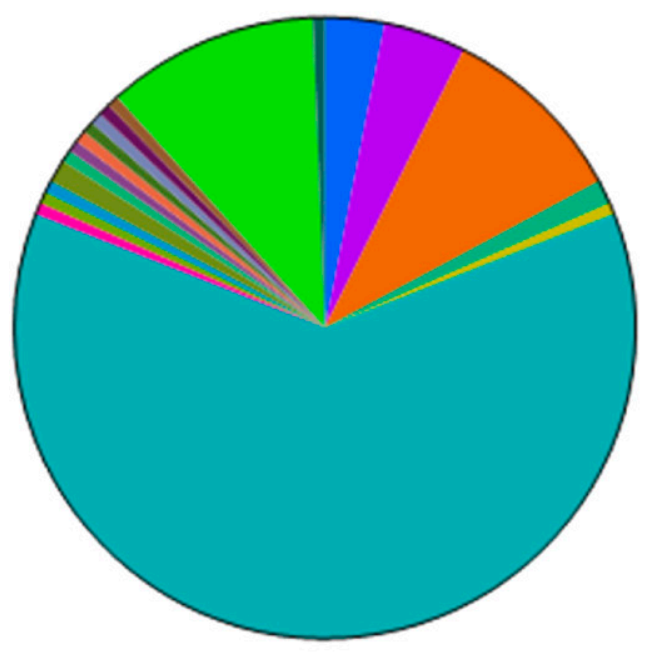

disease resistant

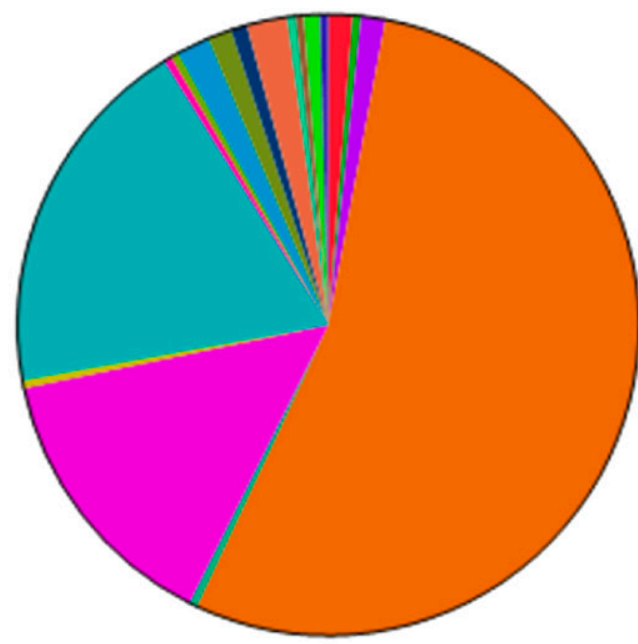

\section{American elm}

Supplemental Fig. 15. American elm insect family comparisons pie chart; disease resistant cultivar and straight species. $35.5 \%$ similarity. (See Supplemental Table 1 for common names of families.) 
control

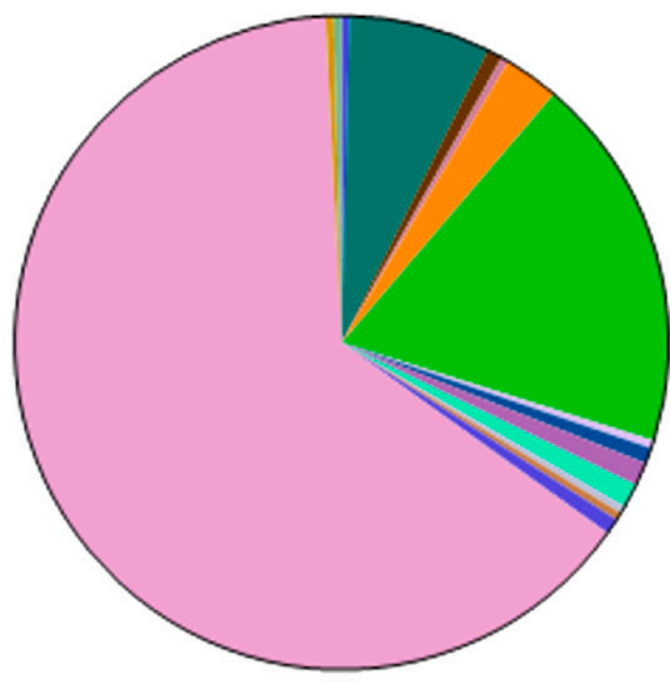

growth habit

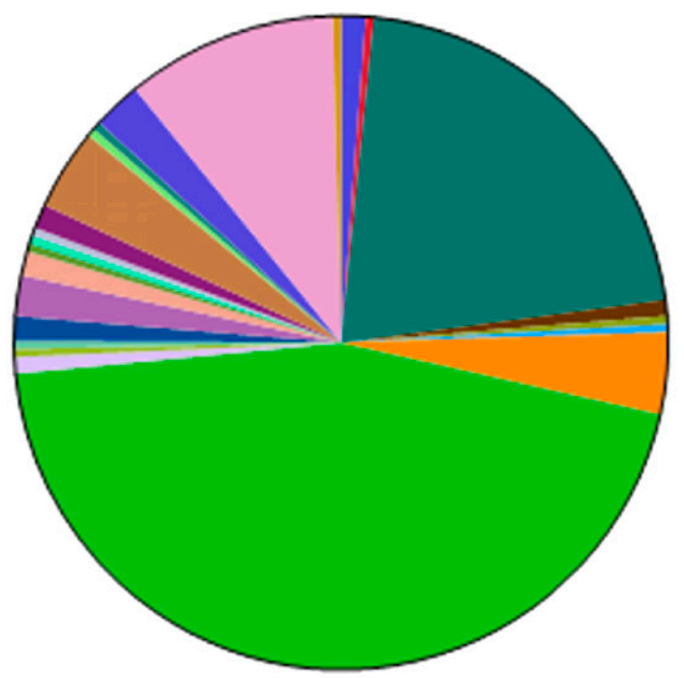

\section{Redosier dogwood}

Supplemental Fig. 16. Redosier dogwood insect family comparisons pie chart; altered growth habit cultivar and straight species. $44.6 \%$ similarity. (See Supplemental Table 1 for common names of families.)
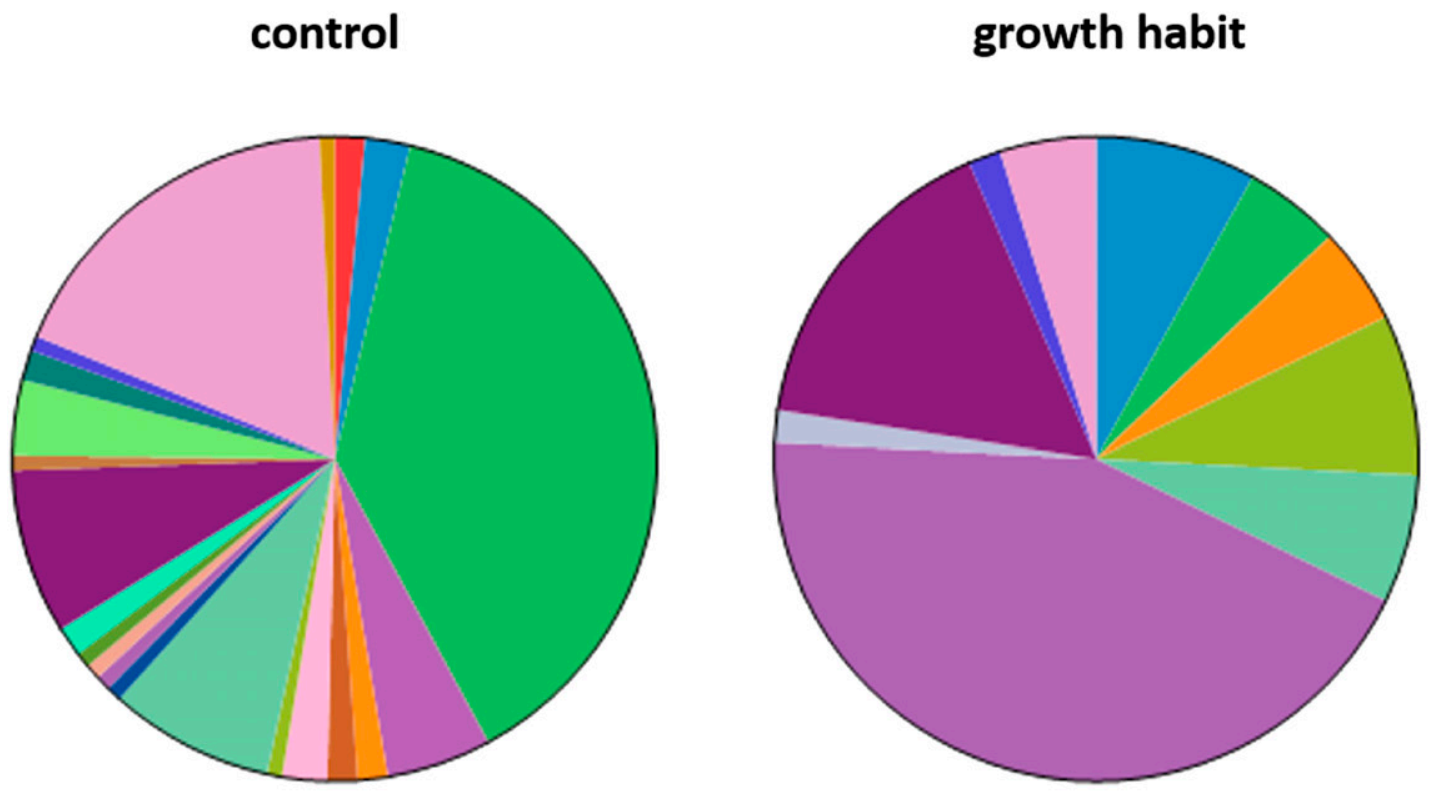

Family

Acanaloniidae
Aleyrodidae
Aphididae
Aphrophoridae
Berytidae
Cecidomyiidae
Cercopidae
Chrysomelidae
Cicadellidae
Coreidae
Diaspididae
Diprionidae
Flatidae
Geometridae
Lygaeidae
Miridae
Pentatomidae
Psocidae
Psychidae
Sminthuridae
Thripidae
Tortricidae

\section{Eastern red cedar}

Supplemental Fig. 17. Eastern red cedar insect family comparisons pie chart; altered growth habit cultivar and straight species. $30.5 \%$ similarity. (See Supplemental Table 1 for common names of families.) 


\section{Research Reports}

\section{control}

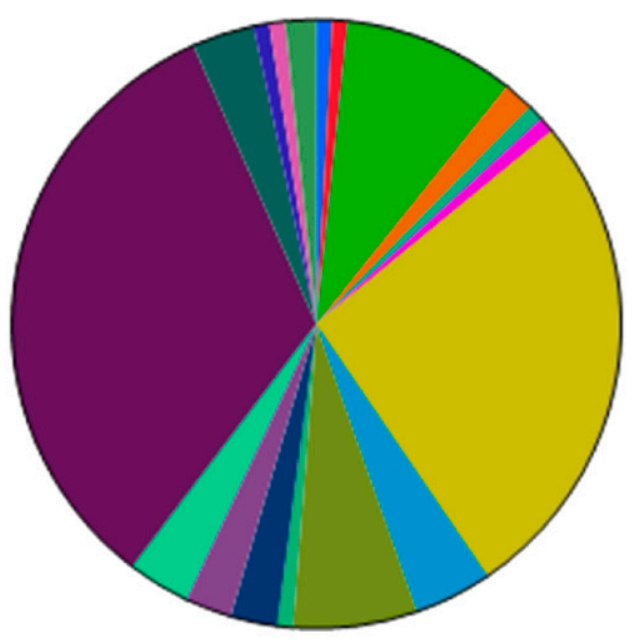

growth habit

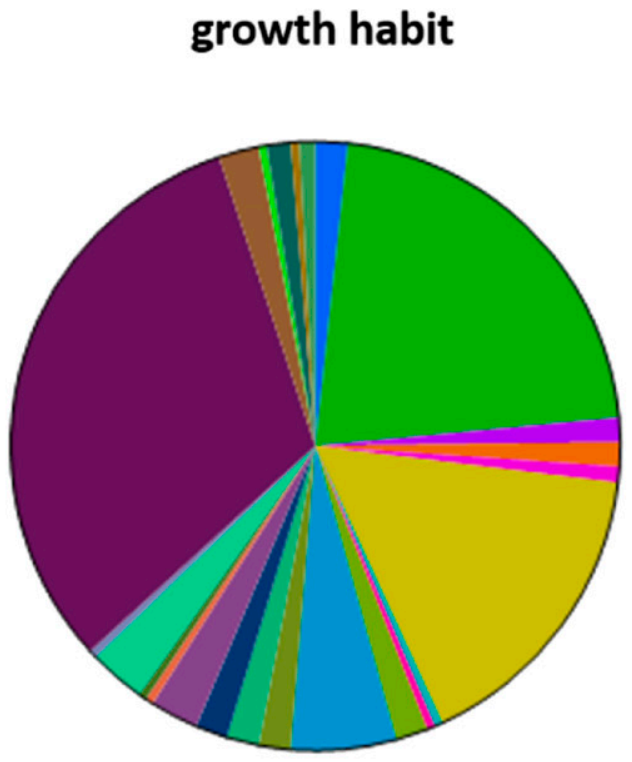

\section{Sweetgum}

Family

Acanaloniidae

Aderidae

Aleyrodidae

Aphididae

Aphrophoridae

Berytidae

Chrysomelidae

Cicadellidae

Diaspididae

Elateridae

Erebidae

Euteliidae

Flatidae

Geometridae

Gryllidae

Membracidae

Noctuidae

Notodontidae

Phlaeothripidae

Psychidae

Pyralidae

Saturniidae

Scarabaeidae

Sminthuridae

Tenthredinidae

Thripidae

Tingidae

unknown Lepidoptera

Supplemental Fig. 18. Sweetgum insect family comparisons pie chart; altered growth habit cultivar and straight species. $75.9 \%$ similarity. (See Supplemental Table 1 for common names of families.) 